\title{
Selectivity of Janus Kinase Inhibitors in Rheumatoid Arthritis and Other Immune-Mediated Inflammatory Diseases: Is Expectation the Root of All Headache?
}

\author{
Masayoshi Harigai $^{1}$ (I) . Suguru Honda ${ }^{1}$ (I)
}

Published online: 17 July 2020

(c) The Author(s) 2020

\begin{abstract}
Janus kinase (JAK) is a signal transducer and activator of a protein transcription system that transduces signals from cell surface cytokine and growth factor receptors to the nucleus. Recently developed JAK inhibitors (JAKinibs) inhibit JAKs nonselectively or selectively and down-regulate the effects of corresponding ligands (i.e. cytokines and growth factors). JAKinibs are efficacious against rheumatoid arthritis and other immune-mediated inflammatory diseases and are being increasingly prescribed clinically. Regarding safety, JAKinib use is associated with common or unique changes in laboratory parameters; however, incidence rates of serious adverse drug reactions (ADRs) associated with these changes are low. Opportunistic and other infections, including tuberculosis, are the most critical ADRs of treatment with JAKinibs, and screening and monitoring of patients should be carefully performed. Incidence rates of herpes zoster (HZ) in patients receiving JAKinibs are high in Japan and Korea, and modestly high in other countries. Filgotinib may not be associated with an elevated risk for HZ, but long-term safety data are lacking. Data from clinical development programmes and post-marketing surveillance have indicated no increased risk for malignancy or serious cardiac events; however, long-term observational studies are necessary. Despite the non-elevated risk of gastrointestinal perforations, patients with older age and/or a history of diverticulitis or receiving non-steroidal anti-inflammatory drugs should be carefully evaluated to determine the risk-benefit balance. The incidence rates of venous thromboembolism with all approved doses are similar to that expected in the population, although there are discrepancies in the placebo-controlled portion of the baricitinib clinical development programmes. Regulatory agencies in the USA and Europe suggested a higher risk for thrombotic events in patients receiving JAKinibs. Pharmacokinetic studies demonstrated that dose adjustment should be considered for JAKinib use in patients with moderate-to-severe renal or hepatic dysfunction, depending on the metabolism of each drug. Long-term observational studies enrolling patients with diverse clinical backgrounds are required to strike a risk-benefit balance in clinical settings.
\end{abstract}

\section{Key Points}

The Janus kinase (JAK)-signal transducer and activator of transcription (STAT) system plays an essential role in the pathogenesis of rheumatoid arthritis (RA) and other immune-mediated inflammatory diseases.

JAK inhibitors (JAKinibs) are efficacious for RA with

Electronic supplementary material The online version of this article (https://doi.org/10.1007/s40265-020-01349-1) contains supplementary material, which is available to authorized users.

Masayoshi Harigai

harigai.masayoshi@twmu.ac.jp various treatment backgrounds; four JAKinibs have been approved and one is under review.

JAK inhibitors with different selectivity to JAK family proteins have similar efficacy and safety profiles in RA patients with some minor differences. 


\section{The Roles of the Janus Kinase (JAK)-Signal Transducer and Activator of Transcription (STAT) System in Health and Diseases}

\subsection{JAK-STAT System}

JAK and STAT proteins are key components of the JAKSTAT systems in mammalian cells. They specifically transmit signals from type I and type II cytokine receptors to the nucleus in response to stimuli of ligands of these receptors, but are not involved in the signalling of tumour necrosis factor (TNF) receptor family, IL-1 receptor family, and G protein-coupled receptors [1, 2]. Four members of the JAK family, namely JAK1, JAK2, JAK3, and Tyk2, and seven of the STAT family, namely STAT1, STAT2, STAT3, STAT4, STAT5A, STAT5B, and STAT6, have been identified. A JAK homodimer or heterodimer comprises a complex with a cytokine/growth factor receptor. Binding of a ligand to a receptor stimulates the dimerisation of its receptors, which activates associated JAKs, leading to auto-phosphorylation of JAKs and phosphorylation of the receptor. STATs in the cytoplasm are recruited to the phosphorylated tyrosine of the receptors via their SH-domains, are phosphorylated by JAK to form dimers, and are transferred to the nucleus to regulate the transcription of DNA [1] (Fig. 1). Each receptor utilises a specific pair of JAKs, and this fact has relevant therapeutic implications for targeting JAKs in various immune-mediated inflammatory diseases (IMIDs). Supplementary Table 1 summarises the combinatorial use of JAKs and STATs in cytokine/growth factor signalling [2].

Binding of ligands (i.e. cytokines or growth factors) to specific receptors triggers conformational changes in the receptors and initiates signal transduction. Subsequently, JAKs are activated and phosphorylate STATs. The phosphorylated STATs form a dimer, which is translocated into the nucleus to regulate transcription. See 1.1 JAK-STAT system for details.

\subsection{Germline Mutations in the JAK-STAT System and Clinical Manifestations}

Germline loss-of-function and gain-of-function mutations observed in the JAK-STAT system are summarised in Supplementary Table $2[1,3]$. In addition to these mutations, genome-wide association studies (GWAS) identified associations between the JAK-STAT system and several diseases as follows: JAK1 and diabetic kidney disease; JAK2 and myeloproliferative neoplasms, inflammatory bowel disease (IBD), and paediatric autoimmune diseases (PADs); TyK2 and IBD, systemic lupus erythematosus (SLE), multiple sclerosis (MS), psoriasis, rheumatoid arthritis (RA), primary biliary cholangitis (PBC), and PADs; STAT1 and

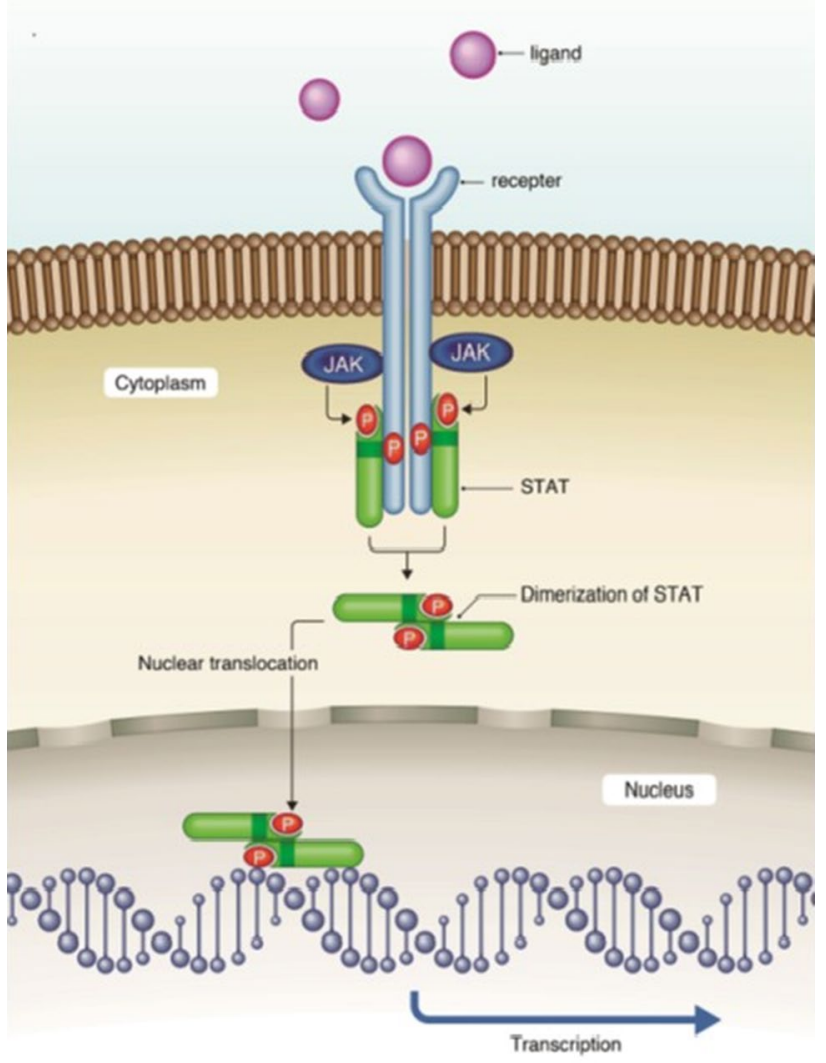

Fig. 1 The JAK-STAT system in human cells

IBD, SLE, and PBC; STAT2 and psoriasis; STAT3 and IBD, MS, atopic dermatitis, and psoriasis; STAT4 and IBD, SLE, RA, Behçet's disease, PBC, Sjögren's syndrome, and systemic sclerosis; and STAT6 and atopy, bronchial asthma, and eosinophilic esophagitis [1].

Most of the reported mutations are associated with susceptibility to various types of infections, suggesting their cardinal roles in host defence against these pathogens. A homozygous mutation of $J A K 3$ is one of the causes of severe combined immunodeficiency (SCID). Patients with SCID are susceptible to severe infectious diseases, including opportunistic infections in early life, and require bone marrow transplantation to save their lives. Patients with JAK3 deficiency show impairments in T-cell development and proliferation, interferon- $\gamma$ production, and interleukin (IL)-4 signalling as well as a decreased number of $\mathrm{CD} 11 \mathrm{c}^{+}$dendritic cells [3]. In a recent case study, a $T y K 2$ frame-shift deletion rendered a patient susceptible to severe or opportunistic infections and caused severe atopic dermatitis and elevation of immunoglobulin E levels. The patient had decreased IL-12 and IL-23 production in response to toll-like receptor 4 or 9 activation and impaired IL-12 and interferon- $\gamma$ signalling [3]. JAK2 mutations are frequently noted in patients 
with myeloproliferative disorders and leukaemia, whereas $J A K$ mutations are seldom observed in patients with solid tumours $[1,3]$. Patients with a loss-of-function mutation in STAT5B develop autoimmune complications resulting from defects in Treg cells [4].

\section{Profiles and Efficacy of JAKinibs in Rheumatoid Arthritis (RA)}

\subsection{Indications for JAKinibs in RA Treatment}

As of March 2020, tofacitinib, baricitinib, and upadacitinib have been approved for treating RA in the USA, EU, Japan, and other countries. Filgotinib is under review by regulatory agencies of these countries. Japan, Korea, and Taiwan approved peficitinib for RA treatment as of May 2020. Indications of JAKinibs for RA differ slightly with countries or regions. For example, the US Food and Drug administration (FDA) states that tofacitinib and upadacitinib may be used to treat adult patients with moderately to severely active RA who have shown an inadequate response or intolerance to methotrexate (MTX) [5, 6]; a maximum dose of $2 \mathrm{mg}$ baricitinib is indicated for those who have shown an inadequate response to one or more tumour necrosis factor inhibitors (TNFi) therapies [7]. Peficitinib is indicated for patients with active RA who have shown an inadequate response to one or more disease-modifying antirheumatic drugs (DMARDs) [8]. The approved JAKinibs can be used both in monotherapies and in combined therapies with MTX or other non-biologic DMARDs, but their combination with other JAKinibs, biological DMARDs, or potent immunosuppressants is not approved for safety concerns. Approved dosages of JAKinibs for treating RA are shown in Table 1.

The 2019 updated European League Against Rheumatism (EULAR) RA management recommendations state that a biological DMARD or targeted synthetic DMARD (i.e. JAKinib) should be added if the treatment target is not achieved with the first conventional synthetic DMARD (csDMARD) strategy in patients with poor prognostic factors [9-11]. The EULAR recommendations strongly suggest that biological DMARDs and targeted synthetic DMARDs should be combined with a csDMARD. Primary indications of JAKinib use for RA are clearly defined in these recommendations by EULAR. Available JAKinibs and their dosages differ across regions or countries as described above.

\subsection{Characteristics of JAKinibs}

The characteristics of JAKinibs are summarised in Table 1 . JAKinibs are classified by their selectivity to JAKs, which is based on preclinical data from enzymatic or biochemical assays. These assays can be impacted by substrate and their results may differ depending on clinical drug concentration. All JAKinibs presented in Table 1 inhibit JAK1. Tofacitinib has additional selectivity for JAK3; baricitinib for JAK2; and peficitinib for JAK2, JAK3, and Tyk2. All JAKinibs target the conserved adenosine triphosphate (ATP)-binding pocket of JAKs [12]. Plasma protein binding varies widely with each JAKinib, ranging from $20.4 \%$ for tofacitinib to $75.2 \%$ for peficitinib. Approximately $30 \%$ of tofacitinib is metabolised by the kidneys and $70 \%$ by the liver. The enzymes responsible for drug metabolism and the routes of excretion of JAKinibs are summarised in Table 1. According to characteristics of metabolism and excretion of tofacitinib and baricitinib, dose adjustment of these drugs is recommended in patients with liver dysfunction or renal impairment. Dose adjustment for peficitinib and upadacitinib is recommended in patients with liver dysfunction. These two JAKinibs need no dose adjustment for renal function, as their renal excretion is negligible, while filgotinib is mainly excreted in urine, and its dosage is currently under review.

\subsection{Efficacy of JAKinibs in Patients with RA}

Tofacitinib, baricitinib, upadacitinib, and peficitinib were reported to be clinically, functionally, and radiologically efficacious at their approved dosages in patients who had inadequate responses to MTX (MTX-IR), those who had inadequate response to a TNFi or other biological DAMRDs (biological DMARD-IR), and in MTX-naïve patients (Figs. 2, 3, and 4 and Supplementary Figs 1, 2, and 3). Since each drug used different study populations, the absolute numbers in the clinical metrics of different molecules (i.e. absolute proportions of ACR20/50/70 response) cannot be compared; yet it is still possible to interpret whether or not a given molecule achieved a specific threshold (i.e. statistical difference in ACR20/50/70 responses from the control group).

In MTX-IR patients, a significantly higher proportion of patients reached ACR20, ACR50, and ACR70 response criteria after receiving JAKinibs with MTX compared to placebo plus MTX at Week 12 (Fig. 2a and Supplementary Fig. 2a) and 24 (Supplementary Figs 1a and 3a), [22-26]. The efficacy of $2 \mathrm{mg}$ baricitinib once daily, which is not shown in Fig. 2a, has been investigated in another randomised controlled trial (RCT) that enrolled patients with RA who showed inadequate response to csDMARDs [27]. Patients received placebo, $2 \mathrm{mg}$ baricitinib once daily, or $4 \mathrm{mg}$ baricitinib once daily with a stable dose of csDMARD. The proportion of patients who met ACR20 response criteria at Week 12, the primary endpoint of the study, was significantly higher in baricitinib groups $(65.9 \%$ for the 2-mg group and $61.7 \%$ for the $4-\mathrm{mg}$ group) versus 


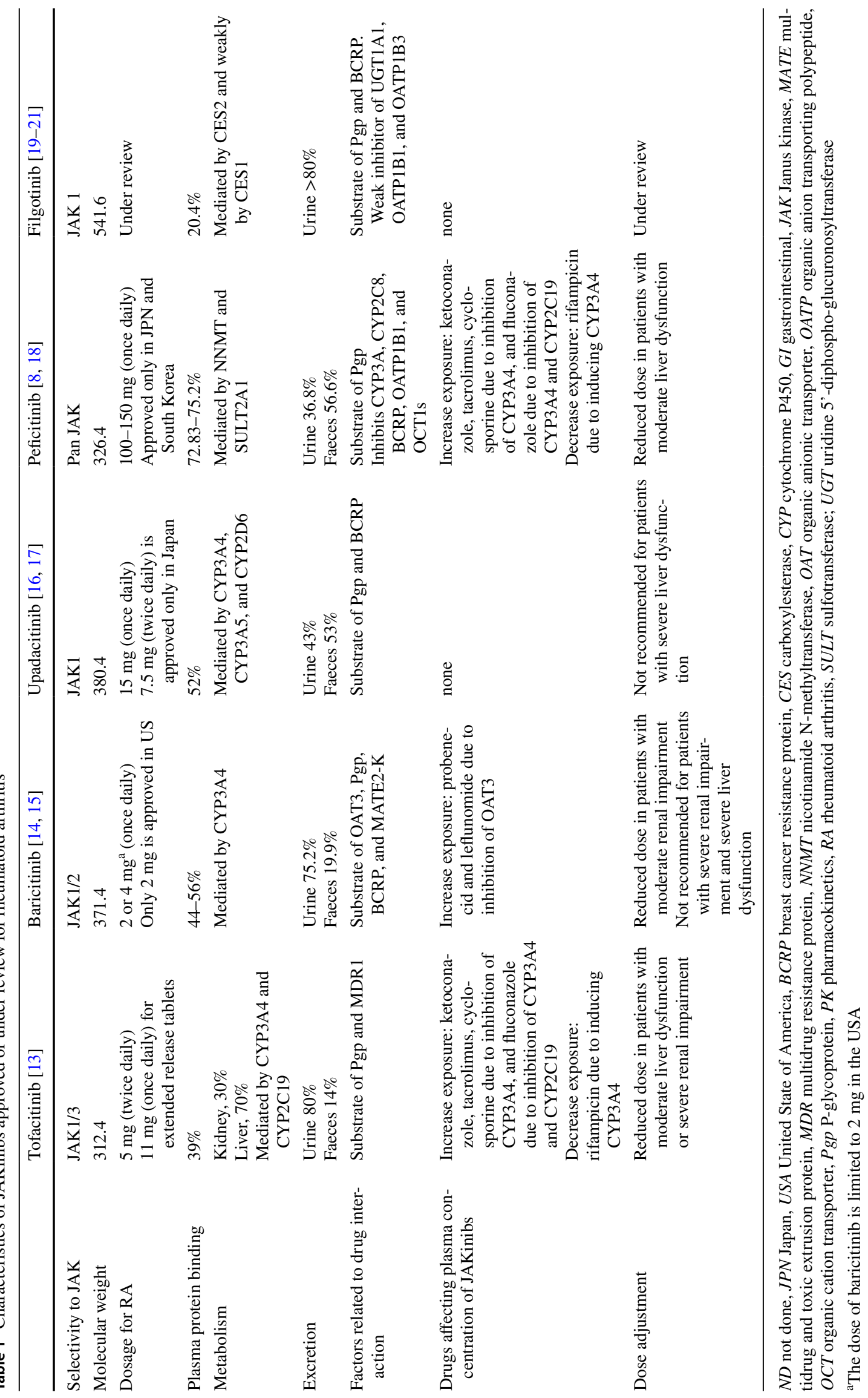


Fig. 2 Clinical efficacy of JAKinibs in patients with rheumatoid arthritis (RA). Clinical efficacy of JAKinibs was assessed using ACR20. Proportions of patients who achieved ACR20 response criteria at week 12 are shown: a patients with RA who showed inadequate response to MTX (MTX-IR) [22-26]; b patients with RA who showed inadequate responses to TNFi or biological DMARDs (biological DMARD-IR) [28-31], and c MTX-naïve patients with RA [32-35]. ACR20 is clinical response criteria developed by the American College of Rheumatology indicating that disease activity of RA decreased by 20\%. P/E indicated whether ACR20 response at week 12 was a primary endpoint $(\mathrm{P} / \mathrm{E})$ of the study or not. If not, the primary endpoint was shown in the parenthesis. Note that the absolute numbers in the clinical metrics of different molecules (i.e. absolute proportions of ACR20/50/70 response) cannot be compared; yet, it is still possible to interpret whether a given molecule achieved a specific threshold or not (i.e. statistical difference in ACR20/50/70 responses from the control group). $* p<0.05$ versus placebo; $* * p<0.001$ versus placebo; ${ }^{\ddagger}$ no studies in biological DMARDs-IR patients; Ino studies in MTX-naïve. Bari baricitinib, Fil filgotinib, MTX methotrexate, $P B O$ placebo, $P e f i$ peficitinib, Tof tofacitinib, $U p a$ upadacitinib (a)

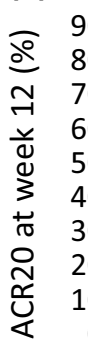

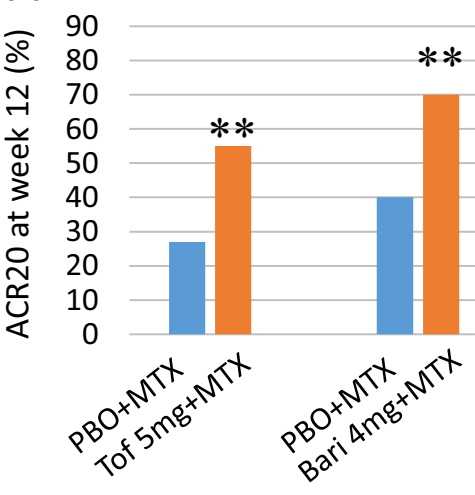

$$
\text { P/E } \underset{\text { (ACR20, wk24) }}{\text { No }}
$$

MTX-IR

(b)
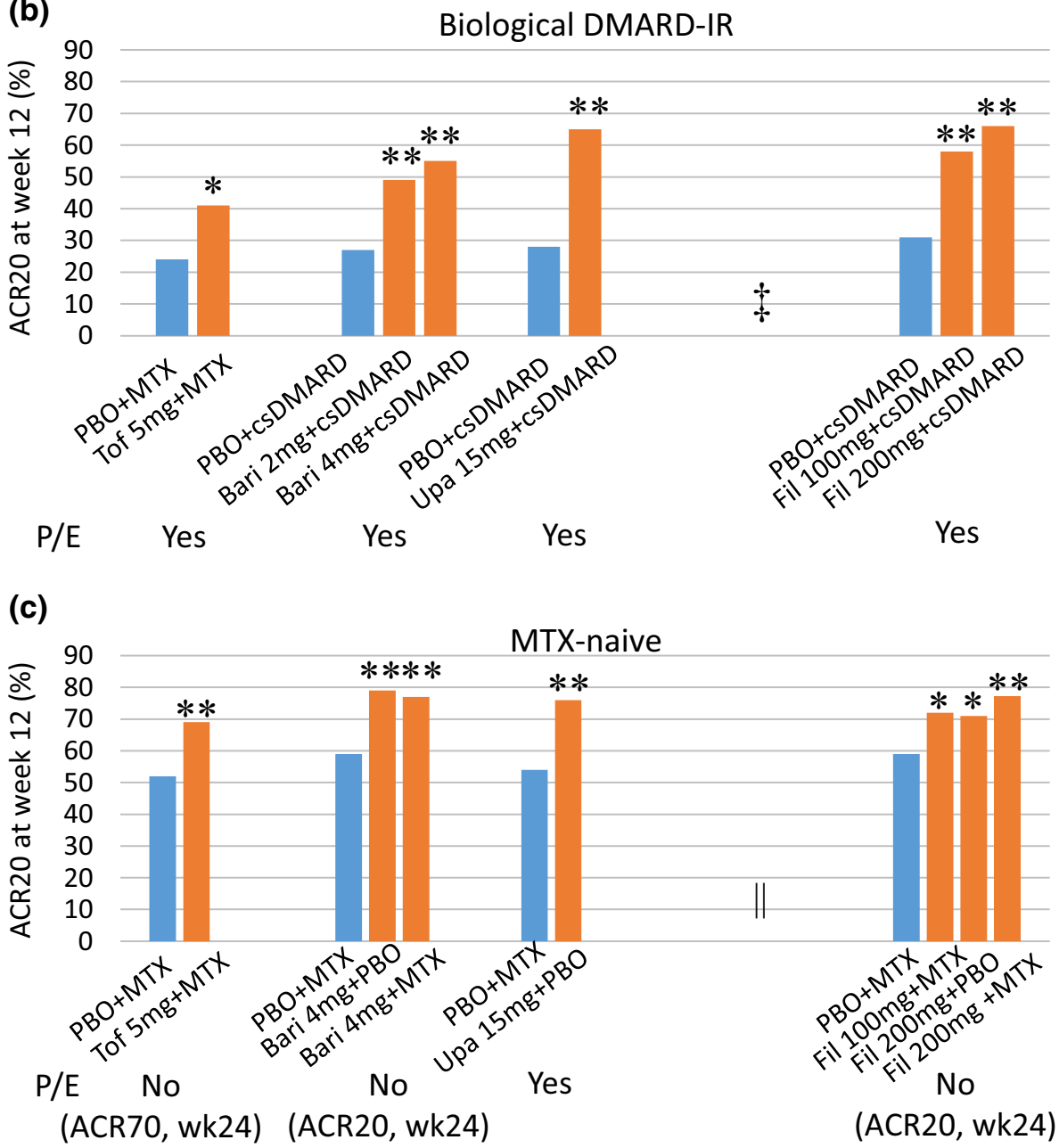

placebo group (39.5\%) $(p \leq 0.001)$. The differences in the responses to placebo across the five trials (Fig. 2) may stem from differences in the countries and regions where they were implemented. Notably, the onset of their efficacy was rapid, usually approximately $1-2$ weeks after starting the therapy, and almost all responders had an ACR20 response by Weeks $8-12$. In addition, JAKinibs improved physical functions of MTX-IR patients, which was measured with health assessment questionnaires-disability index (HAQDI, Fig. 3a).

JAKinibs were also efficacious in biological DMARDIR patients, who are more difficult to treat than MTX-IR 
Fig. 3 Functional efficacy of JAKinibs in patients with rheumatoid arthritis (RA). Functional efficacy of JAKinibs was assessed using Health Assessment Questionnaires-Disability Index (HAQ-DI) in the same RCTs shown in Fig. 2. Mean decreases in HAQ-DI at Week 24 (a, c) or Week 12 (b) are shown: a patients with RA who showed inadequate response to MTX (MTX-IR) [22-26]; b patients with RA who showed inadequate response to TNFi or biological DMARDs (biological DMARD-IR) [28-31], and c MTX-naïve patients with RA [32-35]. * $p<0.05$ versus placebo; $* * p<0.001$ versus placebo; ${ }^{\dagger}$ no data of HAQ-DI change from baseline in baricitinib; ${ }^{\star}$ no studies in biological DMARDs-IR patients; Ino studies in MTX-naïve; "Evaluated at Week 28. Bari baricitinib, Fil filgotinib, MTX methotrexate, $P B O$ placebo, $P e f i$ peficitinib, Tof tofacitinib, Upa upadacitinib
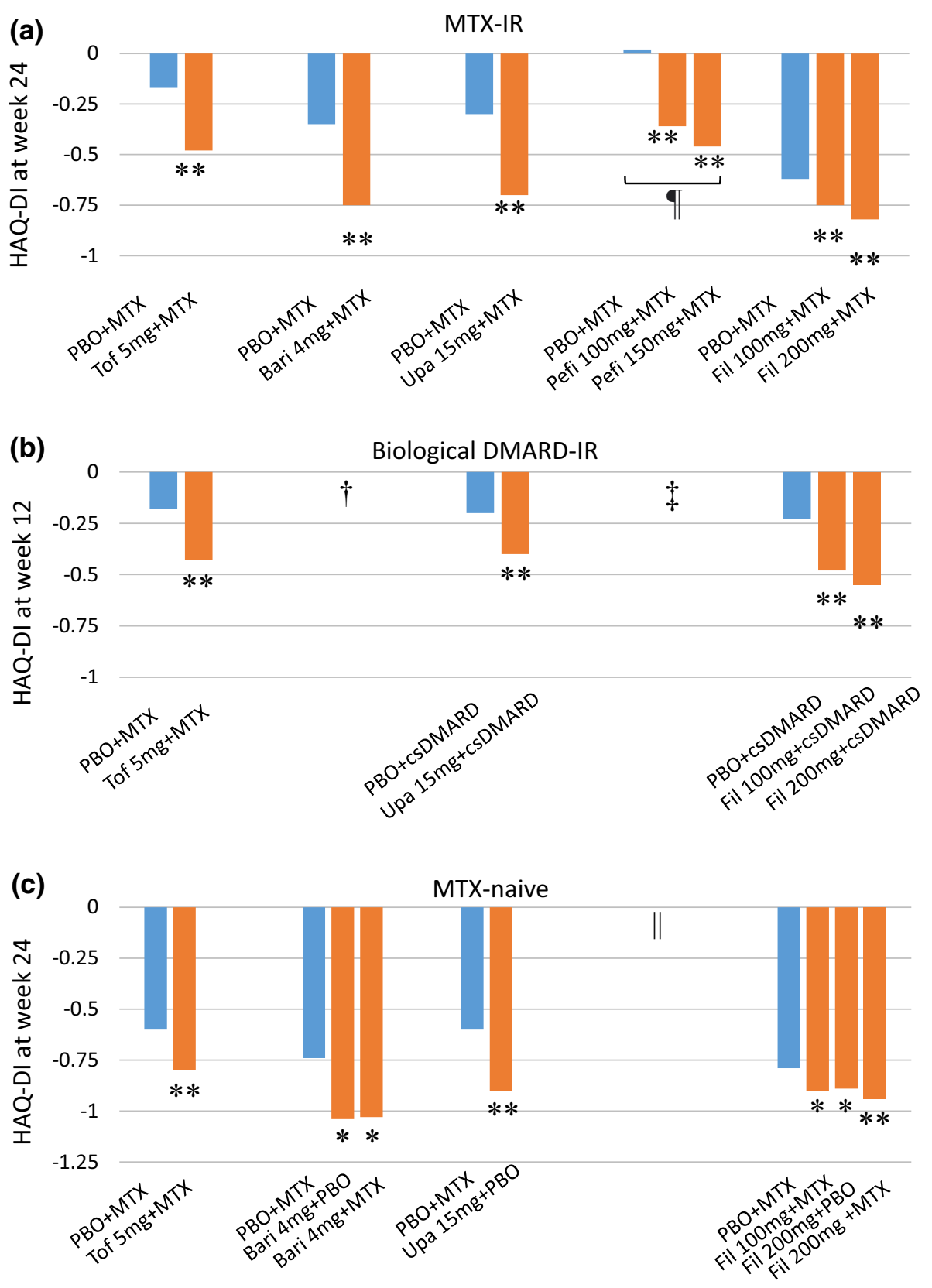

patients [28-31]. A significantly higher proportion of patients reached ACR20 and ACR50 response criteria at Week 12 after treatment with all JAKinibs plus MTX or csDMARDs than after treatment with placebo plus MTX or csDMARD, and the efficacy did not change at Week 24 (Fig. 2b, Supplementary Fig. 1b, 2b, and 3b). ACR 70 response at Week 12 was also significant to $5 \mathrm{mg}$ tofacitinib twice daily, $2 \mathrm{mg}$ and $4 \mathrm{mg}$ baricitinib once daily, and $200 \mathrm{mg}$ filgotinib once daily versus placebo. HAQ-DI decreased significantly after treatment with JAKinibs in these patient populations (Fig. 3b). RCTs were implemented in MTX-naïve patients with RA [32-35]. While comparator arms were placebo + MTX in all four clinical trials, test arms were different; $5 \mathrm{mg}$ tofacitinib twice daily + MTX; $4 \mathrm{mg}$ baricitinib once daily + placebo and $4 \mathrm{mg}$ baricitinib once daily + MTX; $15 \mathrm{mg}$ upadacitinib once daily + placebo; $100 \mathrm{mg}$ filgotinib once daily + MTX, $200 \mathrm{mg}$ filgotinib once daily + placebo, and $200 \mathrm{mg}$ filgotinib once daily + MTX. A significantly better clinical response was reported for JAKinibs versus MTX in all trials except $200 \mathrm{mg}$ filgotinib + placebo for ACR20 response at Week 24, the primary endpoint of the study (Fig. 2c and Supplementary Figs 1c, 2c, and 3c). HAQ-DI also decreased significantly after treatment with JAKinibs in these patient populations (Fig. 3c).

All JAKinibs plus MTX significantly suppressed the progression of structural changes in the joints at Weeks 
Fig. 4 Radiological efficacy of JAKinibs in patients with rheumatoid arthritis (RA). Radiological efficacy of JAKinibs was assessed using van der Heijde-modified Total Sharp Score (vdH-mTSS), a quantifying tool for joint structural damage. Mean decreases in vdH-mTSS are shown in: a patients with RA who had inadequate response to MTX (MTX-IR) [22-26]; b MTXnaïve patients with RA [32-35]. $\mathrm{vdH}$-mTSS was assessed at baseline and Week 24 following tofacitinib, baricitinib, and filgotinib treatment, at Week 26 following upadacitinib treatment, and at Week 28 following peficitinib treatment in patients with RA who showed inadequate response to MTX [22, 24-27]. b vdH-mTSS was assessed at baseline and Week 24. * $p<0.05$ versus placebo; ** $p<0.001$ versus placebo; Ino studies in MTX-naïve. Bari baricitinib, Fil filgotinib, MTX methotrexate, $P B O$ placebo, $P e f i$ peficitinib, Tof tofacitinib, Upa upadacitinib
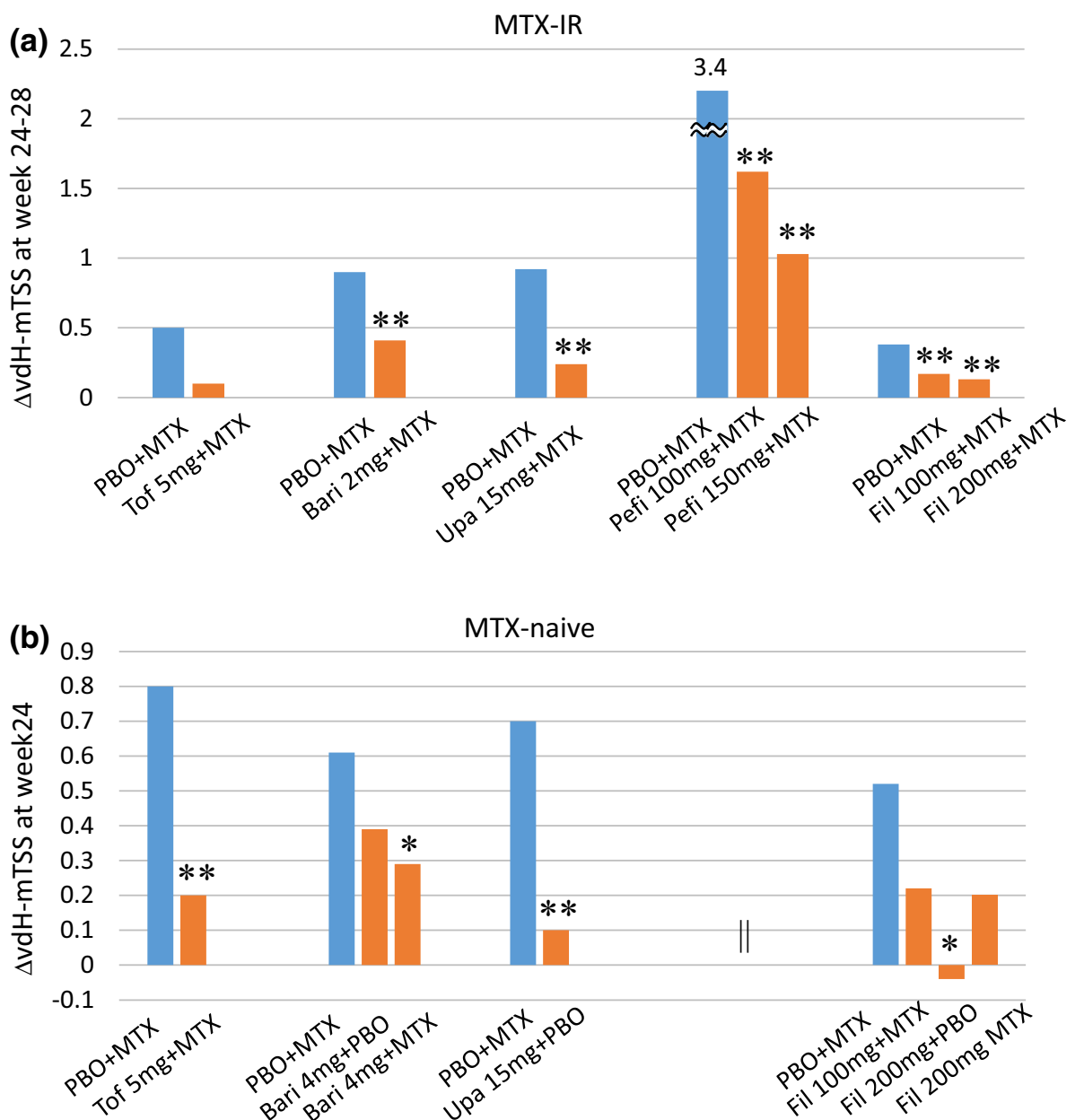

24-28 (depending on JAKinibs tested) compared with placebo plus MTX in MTX-IR patients with RA except for $5 \mathrm{mg}$ tofacitinib twice daily [22, 24-27] (Fig. 4a). However, tofacitinib plus MTX significantly inhibited the progression of structural changes at Week 24 in MTX-naïve patients with RA as well as $4 \mathrm{mg}$ baricitinib plus MTX, $15 \mathrm{mg}$ upadacitinib plus placebo, and $200 \mathrm{mg}$ filgotinib plus placebo (Fig. 4b). The progression of joint destruction in the placebo group was higher in the clinical trial of peficitinib, which may have been due to ethnic differences in the susceptibility to joint destruction by RA.

Clinical efficacy of JAKinibs and adalimumab was compared in RCTs of tofacitinib, baricitinib, and upadacitinib. Adalimumab is used as a standard-of-care biologic DMARD for RA with moderate-to-severe disease activity. The results were summarised in Table 2. In MTX-IR patients with RA, tofacitinib + MTX effects were noninferior to adalimumab + MTX at Month 6 for ACR50 response, while superiority could not be significantly proven. Baricitinib + MTX was superior as well as noninferior to adalimumab + MTX in MTX-IR patients with RA at Week 12 for ACR20 response. Upadacitinib + MTX was superior as well as non-inferior to adalimumab + MTX in MTX-IR patients with RA at Week 12 for ACR50 response and DAS28-CRP $<3.2$.

\section{JAKinibs in Other IMIDs}

The efficacy and safety of JAKinibs have been evaluated in various IMIDs [37] (Table 3). Of these, tofacitinib is approved to treat ulcerative colitis (UC) in the USA, the EU and Japan and psoriatic arthritis (PsA) in the USA as of May $2020[5,13,38]$. According to the USA FDA, tofacitinib is indicated for adult patients with moderately to severely active UC who have showed inadequate response or who are intolerant to TNFi. The recommended dose of tofacitinib is $10 \mathrm{mg}$ (twice daily) as an induction therapy for 8 weeks and for a maximum of 16 weeks if needed. This is followed by $5 \mathrm{mg}$ (twice daily) for maintenance therapy. In addition, tofacitinib is indicated for the treatment of adult patients with PsA who showed inadequate response or intolerance to MTX or other DMARDs. The recommended doses for PsA are the same as those for RA, but tofacitinib is not 
Table 2 Comparison of JAKinibs and adalimumab for clinical efficacy

\begin{tabular}{|c|c|c|c|c|c|c|}
\hline JAKinibs & Patients & Endpoint & Efficacy by treatment group & & Treatment difference & Versus comparator \\
\hline Tofacitinib [36] & MTX-IR & ACR50 at month 6 & $\begin{array}{l}\text { Tof } 5 \mathrm{mg} \text { bid + PBO } \\
\text { Tof } 5 \mathrm{mg} \text { bid + MTX } \\
\text { ADA } 40 \mathrm{mg} \text { biweekly + MTX }\end{array}$ & $\begin{array}{l}38 \% \\
46 \% \\
44 \%\end{array}$ & $\begin{array}{l}\text { Tof + MTX vs ADA + MTX, } \\
2.2 \%(98.34 \% \text { CI }-6.4 \text { to } \\
10.9) \\
\text { Tof + PBO vs ADA + MTX, } \\
-5.5 \%(98.34 \% \mathrm{CI}-14.0 \\
\text { to } 3.0) \\
\text { Tof + PBO vs Tofa + MTX, } \\
-7.7 \% \text { [98.34\% CI }-16.3 \\
\text { to } 0.8]) \\
\text { Prespecified non-inferiority } \\
\text { margin }=-13 \%\end{array}$ & $\begin{array}{l}\text { Non-inferior }^{\mathrm{a}} \\
\text { Not non-inferior }^{\mathrm{a}} \\
\text { Not non-inferior }^{\mathrm{a}}\end{array}$ \\
\hline Baricitinib [23] & MTX-IR & ACR20 at week 12 & $\begin{array}{l}\text { PBO + MTX } \\
\text { Bari } 4 \text { mg qd + MTX } \\
\text { ADA } 40 \text { mg biweekly + MTX }\end{array}$ & $\begin{array}{l}40.2 \% \\
69.6 \% \\
61.2 \%\end{array}$ & $\begin{array}{l}\text { Bari + MTX vs ADA + MTX, } \\
8.4 \text { (95\% CI } 1.7 \text { to } 15.1) \\
\text { Prespecified non-inferiority } \\
\text { margin }=-12 \%\end{array}$ & Superior $^{b}$ \\
\hline \multirow[t]{3}{*}{ Upadacitinib [25] } & MTX-IR & ACR50 at week 12 & $\begin{array}{l}\mathrm{PBO}+\mathrm{MTX} \\
\text { Upa } 15 \mathrm{mg} \mathrm{qd}+\text { MTX } \\
\text { ADA } 40 \mathrm{mg} \text { biweekly + MTX }\end{array}$ & $\begin{array}{l}15 \% \\
45 \% \\
29 \%\end{array}$ & $\begin{array}{l}\text { Upa + MTX vs ADA + MTX, } \\
\text { 16.1 (95\% CI 9.9-22.3) } \\
\text { Upa + MTX vs PBO + MTX, } \\
\text { 30.3\% (95\% CI 25.6-35.0) } \\
\text { Prespecified margin for non- } \\
\text { inferiority of Upa compared } \\
\text { to ADA }=-10 \%\end{array}$ & $\begin{array}{l}\text { Superior } \\
\text { Superior }^{c}\end{array}$ \\
\hline & & DAS28-CRP $<2.6$ at week 12 & $\begin{array}{l}\text { PBO + MTX } \\
\text { Upa } 15 \mathrm{mg} \mathrm{qd}+\text { MTX } \\
\text { ADA } 40 \mathrm{mg} \text { biweekly + MTX }\end{array}$ & $\begin{array}{l}6 \% \\
29 \% \\
18 \%\end{array}$ & $\begin{array}{c}\text { Upa + MTX vs ADA + MTX, } \\
10.7(95 \% \text { CI 5.3-16.1) } \\
\text { Upa + MTX vs PBO+MTX, } \\
22.6 \%(95 \% \text { CI 18.6-26.5) } \\
\text { Non-inferiority compari- } \\
\text { son of Upa vs ADA was } \\
\text { not planned for DAS28- } \\
\text { CRP }<2.6 \text { at week } 12 .\end{array}$ & $\begin{array}{l}\text { Superior }^{\mathrm{d}} \\
\text { Superior }^{\mathrm{d}}\end{array}$ \\
\hline & & DAS28-CRP $<3.2$ at week 12 & $\begin{array}{l}\text { PBO + MTX } \\
\text { Upa } 15 \text { mg qd + MTX } \\
\text { ADA } 40 \text { mg biweekly + MTX }\end{array}$ & $\begin{array}{l}14 \% \\
45 \% \\
29 \%\end{array}$ & $\begin{array}{c}\text { Upa + MTX vs ADA + MTX, } \\
16.3 \% \text { (95\% CI 10.0-22.5) } \\
\text { Upa + MTX vs PBO + MTX } \\
\text { Prespecified margin for non- } \\
\text { inferiority of Upa compared } \\
\text { to ADA }=-10 \%\end{array}$ & $\begin{array}{l}\text { Superior } \\
\text { Superior }^{\mathrm{f}}\end{array}$ \\
\hline
\end{tabular}

In all three RCTs, patients received a matching placebo SC injection biweekly

ACR50 50\% response according to the criteria of the American College of Rheumatology, ADA adalimumab, Bari baricitinib, $C I$ confidence interval, DAS28-CRP Disease Activity Score for 28 joints (DAS28) with the use of high-sensitivity C-reactive protein, $M T X$ methotrexate, $P B O$ placebo, Tof tofacitinib, Upa upadacitinib

${ }^{\text {a }}$ Superiority was not shown for any comparison between the treatment groups

${ }^{\mathrm{b}}$ Baricitinib was found to be non-inferior to adalimumab. According to the statistical analysis plan, baricitinib was considered to be significantly superior to adalimumab $(p=0.01)$

${ }^{c}$ Upadacitinib was non-inferior to adalimumab and met the multiplicity-controlled superiority comparison to adalimumab plus placebo for the ACR50 response rate ( $p \leq 0.001$ for both)

${ }^{\mathrm{d}}$ Nominal $p \leq 0.001$ for upadacitinib versus adalimumab and $p \leq 0.001$ for upadacitinib vs placebo

${ }^{\mathrm{e}}$ Upadacitinib met the multiplicity-controlled non-inferiority comparison to adalimumab and subsequently superior to adalimumab with $p \leq$ 0.001

f $p \leq 0.001$ for upadacitinib vs placebo

approved as a monotherapy. A Phase III RCT demonstrated superior efficacy of tofacitinib versus placebo in csDMARDIR patients with PsA [39]. There were significant improvements for tofacitinib versus placebo in ACR20 response at Month 3 (5 mg twice daily 50\%, $10 \mathrm{mg}$ twice daily $61 \%$, and placebo $33 \% ; p=0.01$ for $5 \mathrm{mg}$ vs placebo, $p<0.001$ for $10 \mathrm{mg}$ vs placebo) and change in HAQ-DI at Month 3 (5 mg twice daily $-0.35,10 \mathrm{mg}$ twice daily -0.40 , and placebo $-0.18 ; p=0.006$ for $5 \mathrm{mg}$ vs placebo, $p<0.001$ for $10 \mathrm{mg}$ vs placebo). Tofacitinib was also efficacious in patients with PsA who showed inadequate response to a TNF inhibitor. Significantly larger proportions of patients achieved ACR20 response at Month 3, the primary endpoint, in the tofacitinib group versus placebo group $(5 \mathrm{mg}$ twice daily $50 \%, 10 \mathrm{mg}$ twice daily $47 \%$, placebo $24 \% ; p<0.001$ for both tofacitinib groups vs placebo) [40]. A Phase II RCT demonstrated the efficacy of filgotinib in csDMARD-IR patients with PsA. There was a significant improvement in 
Table 3 Phase II and Phase III studies of JAKinibs in other immune-mediated inflammatory diseases registered in ClinicalTrials.gov [37]

\begin{tabular}{|c|c|c|c|c|c|}
\hline IMID & Tofacitinib & Baricitinib & Upadacitinib & Peficitinib & Filgotinib \\
\hline SLE/DLE & $\begin{array}{l}\text { Phase II (03288324, } \\
03159936)\end{array}$ & $\begin{array}{l}\text { Phase III }(03843125, \\
\text { 03616964, } \\
03616912)\end{array}$ & Phase II (03978520) & & $\begin{array}{l}\text { Phase II (03285711, } \\
03134222)\end{array}$ \\
\hline IIM & & Phase II (04208464) & & & \\
\hline $\mathrm{SSc}$ & Phase II (03274076) & & & & \\
\hline SS & & & & & Phase II (03100942) \\
\hline SpA & Phase III (03738956) & & Phase III (04169373) & & \\
\hline AS & Phase III (03502616) & & Phase II (03178487) & & Phase II (03117270) \\
\hline PsA & Approved (USA) & & $\begin{array}{l}\text { Phase III (03104374, } \\
03104400)\end{array}$ & & $\begin{array}{l}\text { Phase III (04115839, } \\
04115748)\end{array}$ \\
\hline Psoriasis & $\begin{array}{l}\text { Phase III (01163253, } \\
\text { 01815424, 01309737, } \\
01276639, \\
\text { 01519089, 01186744, } \\
01241591)\end{array}$ & Phase II (01490632) & & Phase II (01096862) & \\
\hline JIA & $\begin{array}{l}\text { Phase III (02592434, } \\
01500551)\end{array}$ & $\begin{array}{l}\text { Phase III (03773965, } \\
03773978)\end{array}$ & & & \\
\hline sJIA & Phase III (03000439) & Phase III (04088396) & & & \\
\hline PMR & Phase II & Phase II (04027101) & & & \\
\hline Takayasu arteritis & & & Phase III (04161898) & & \\
\hline GCA & Phase II & Phase II (03026504) & Phase III (03725202) & & \\
\hline UC & $\begin{array}{l}\text { Approved (USA, EU, } \\
\text { JPN) }\end{array}$ & & $\begin{array}{l}\text { Phase III }(03006068, \\
03653026, \\
02819635)\end{array}$ & Phase II (01959282) & $\begin{array}{l}\text { Phase III (02914535, } \\
02914522)\end{array}$ \\
\hline $\mathrm{CD}$ & $\begin{array}{l}\text { Phase II }(01393899, \\
01393626,01470599, \\
00615199)\end{array}$ & & $\begin{array}{l}\text { Phase III (03345836, } \\
03345823 \text {, } \\
03345849)\end{array}$ & & $\begin{array}{l}\text { Phase III (02914600, } \\
\text { 02914561) }\end{array}$ \\
\hline PBC & & Phase II (03742973) & & & \\
\hline Non-infectious uveitis & Phase II (03580343) & Phase III (04088409) & & & Phase II (03207815) \\
\hline Alopecia & $\begin{array}{l}\text { Phase II (02299297, } \\
\text { 02812342, } \\
02197455)\end{array}$ & Phase III (03899259) & & & \\
\hline Atopic dermatitis & Phase II (02001181) & $\begin{array}{l}\text { Phase III }(03559270, \\
03334422,03952559, \\
03334396,03435081, \\
03733301,03334435, \\
03428100)\end{array}$ & $\begin{array}{l}\text { Phase III }(04195698, \\
03569293,03568318, \\
03607422,03661138, \\
03738397)\end{array}$ & & \\
\hline
\end{tabular}

NTC number is shown in the parenthesis

Data were obtained from the website of ClinicalTrials.gov at https://clinicaltrials.gov/

Ruxolitinib, a JAK1 and JAK2 inhibitor, is approved for myeloproliferative neoplasms but is not included in this table

$C D$ Crohn's disease, $D L E$ discoid lupus erythematosus, $E U$ European Union, GCA giant cell arteritis, GVH graft versus host disease, $I I M$ idiopathic inflammatory myositis, $I M I D$ immune-mediated inflammatory disease, $J I A$ juvenile idiopathic arthritis, $J P N$ Japan, $P B C$ primary biliary cholangitis, $P M R$ polymyalgia rheumatica, $S J I A$ systemic juvenile idiopathic arthritis, $S L E$ systemic lupus erythematosus, $S p A$ spondyloarthritis, $S S$ systemic sclerosis, SSC systemic sclerosis, $U C$ ulcerative colitis

a proportion of patients who achieved ACR20 response at Week 16 for $200 \mathrm{mg}$ filgotinib versus placebo ( $80 \%$ vs $33 \%$; treatment difference $47 \%$; $95 \%$ confidence interval $(95 \% \mathrm{CI})$ 30.2-59.6) [41].

While tofacitinib failed in the Phase II clinical trials for Crohn's disease [42], a Phase II clinical trial of filgotinib with active Crohn's disease met its primary endpoint [43]. Patients $(n=174)$ were randomly assigned $(3: 1)$ to receive
$200 \mathrm{mg}$ filgotinib or placebo once daily for 10 weeks. Intention-to-treat analysis revealed that $60(47 \%)$ of 128 patients treated with $200 \mathrm{mg}$ filgotinib achieved clinical remission at Week 10 versus ten $(23 \%)$ of 44 patients treated with placebo (difference 24 percentage points [95\% CI 9-39], $p=0.0077$ ). Upadacitinib was also investigated in patients with Crohn's disease. A Phase II clinical trial enrolling 220 patients with moderate-to-severe Crohn's disease demonstrated that 
upadacitinib induced endoscopic remission in a significant proportion of patients, compared with placebo [44]. Phase III clinical trials are being implemented with these JAKinibs. Discordance of the results of clinical trials for Crohn's disease may stem from study design or selectivity of JAKinibs, but we should wait for results from ongoing Phase III clinical trials to draw a conclusion.

Efficacy and safety of four JAKinibs (tofacitinib, baricitinib, upadacitinib, and filgotinib) have been investigated in patients with systemic lupus erythematosus (SLE). Phase II study of baricitinib enrolled 314 patients with SLE who had SLEDAI- 2 K score $\geq 4$ based on clinical symptoms and had active arthritis and/or active rash as defined by the SLEDAI-2 $\mathrm{K}$ at randomisation. Patients were allocated to one of the three arms: placebo, $2 \mathrm{mg}$ baricitinib, or $4 \mathrm{mg}$ baricitinib. At Week 24, the proportion of the patients in the 4-mg baricitinib group who achieved the primary endpoint (defined as the resolution of SLEDAI-2 K arthritis or rash) was significantly higher than that in placebo group (odds ratio [OR] vs placebo $1.8,95 \%$ CI $1.0-3.3 ; p=0.0414$ ) [45]. A Phase III study on baricitinib in patients with active SLE is currently being implemented. A Phase II study on filgotinib in cutaneous lupus erythematosus (NTC\#03134222) did not meet its primary endpoint and another study in lupus membranous nephropathy (NTC\#03285711) was stopped because of low enrolment. Two Phase II studies on tofacitinib in discoid lupus erythematosus and SLE with cutaneous disease and one Phase II study with upadacitinib in moderately to severely active SLE are recruiting participants (Table 3 and https://clinicaltrials.gov/).

Clinical trials in patients with ankylosing spondylitis (AS) are also promising. A randomised, placebo-controlled, Phase II trial compared placebo, $2 \mathrm{mg}$ tofacitinib twice daily, $5 \mathrm{mg}$ twice daily, and $10 \mathrm{mg}$ twice daily. The primary efficacy endpoint was the response rate at Week 12 analysed by Assessment of SpondyloArthritis International Society for $20 \%$ improvement (ASAS20) with the Bayesian EMAX model. Administering 5 and $10 \mathrm{mg}$ tofacitinib twice daily demonstrated greater clinical efficacy than placebo in reducing signs, symptoms and objective endpoints of active AS in adult patients [46]. In the Phase II RCT of filgotinib, patients with active AS $(n=116)$ were randomly allocated to $200 \mathrm{mg}$ filgotinib once daily or to placebo (1:1 ratio) [47]. The change in the mean AS disease activity score (ASDAS) from baseline to Week 12, the primary endpoint, was -1.47 in the filgotinib group vs -0.57 in the placebo group (least squares mean difference - 0.85; $95 \% \mathrm{CI}-0.17$ to $-0.53 ; p<0.0001)$. Decrease in ASDAS was already significant at Week 1 . In the Phase II/III RCT of upadacitinib, 93 patients with active AS received upadacitinib and 94 received placebo [48]. Significantly more patients in the upadacitinib group versus the placebo group had an ASAS40 response at Week 14, the primary endpoint of the study (52\% vs $26 \%$; treatment difference $26 \%$; $95 \%$ CI $13-40 ; p=0.0003)$.

\section{Safety Profiles of JAKinibs}

\subsection{Changes in Laboratory Parameters}

The safety data for JAKinibs have been extensively collected and analysed in clinical development programs (CDPs) and post-marketing surveillance studies for RA and other IMIDs. Changes in laboratory parameters of patients with RA treated with JAKinib that were obtained from CDPs are summarised in Table 4 [24, 30, 31, 49-55]. Some differences were observed in the levels of haemoglobin, lymphocyte counts, and platelet counts. The net effect of JAKinibs on haemoglobin levels and platelet counts is complex because of the effect of RA-associated inflammation on these laboratory parameters and different selectivity of JAKinibs to JAK2, which is used by erythropoietin receptors and thrombopoietin receptors (Supplementary Table 1). Haemoglobin levels increase after treatment with all JAKinibs except upadacitinib. Partial inhibition of JAK2 could be responsible for the decrease in haemoglobin levels in patients treated with upadacitinib. Platelet counts decrease following treatment with all JAKinibs except baricitinib, which showed transient increase in platelet counts before returning to normal levels. Lymphocyte counts remain stable following filgotinib treatment but decreased after other JAKinibs therapies. Increased levels of serum liver transaminases, creatine kinase, highdensity lipoprotein cholesterol, low-density lipoprotein cholesterol, and creatinine are common across all JAKinibs therapies. Incidence rates of serious adverse events (AEs) associated with these changes in laboratory parameters are low and seldom lead to the cessation of treatment with a JAKinib.

\subsection{AEs of Interest Associated with JAKinib Treatment}

The incidence rates of AEs of interest associated with tofacitinib, baricitinib, peficitinib, upadacitinib, and filgotinib treatment in patients with RA are summarised in Table 5 [18, 56-63]. It is important to note that patient-years (PYs) for tofacitinib and baricitinib are larger than those of other three JAKinibs. Overall, safety profiles of JAKinibs are quite similar irrespective of their selectivity to JAKs. Incidence rates of serious infection and herpes zoster (HZ) with filgotinib might be lower than with other JAKinibs, but more data are required to discuss the difference. Details of each AE are discussed in the following sections. 
Table 4 Effects of JAKinibs on laboratory parameters

\begin{tabular}{|c|c|c|c|c|c|}
\hline Laboratory parameters & Tofacitinib $[49,50]$ & Baricitinib [51] & Upadacitinib $[30,53]$ & Peficitinib $[24,52]$ & Filgotinib $[31,54,55]$ \\
\hline Haemoglobin & Gradual increase & Gradual increase & Decrease $^{\mathrm{a}}$ & Gradual increase & Gradual increase \\
\hline Lymphocyte count & Gradual decrease & Gradual decrease & Decrease $^{\mathrm{a}}$ & Gradual decrease & Stable \\
\hline Platelet count & $\begin{array}{l}\text { Instant decrease fol- } \\
\text { lowed by stabilisa- } \\
\text { tion }\end{array}$ & Transient increase & $\begin{array}{l}\text { Instant decrease fol- } \\
\text { lowed by stabilisa- } \\
\text { tion }\end{array}$ & Decrease $^{a}$ & Decrease $^{a}$ \\
\hline Liver transaminases & $\begin{array}{l}\text { Instant increase fol- } \\
\text { lowed by stabilisa- } \\
\text { tion }\end{array}$ & $\begin{array}{l}\text { Instant increase fol- } \\
\text { lowed by stabilisa- } \\
\text { tion }\end{array}$ & Increase $^{\mathrm{a}}$ & Increase $^{a}$ & Increase $^{a}$ \\
\hline Creatinine kinase & Increase $^{\mathrm{a}}$ & Increase $^{\mathrm{a}}$ & Increase $^{a}$ & Increase $^{a}$ & Increase $^{a}$ \\
\hline HDL cholesterol & $\begin{array}{l}\text { Instant increase fol- } \\
\text { lowed by stabilisa- } \\
\text { tion }\end{array}$ & $\begin{array}{l}\text { Instant increase fol- } \\
\text { lowed by stabilisa- } \\
\text { tion }\end{array}$ & $\begin{array}{l}\text { Instant increase fol- } \\
\text { lowed by stabilisa- } \\
\text { tion }\end{array}$ & $\begin{array}{l}\text { Instant increase fol- } \\
\text { lowed by stabilisa- } \\
\text { tion }\end{array}$ & Increase $^{a}$ \\
\hline LDL cholesterol & $\begin{array}{l}\text { Instant increase fol- } \\
\text { lowed by stabilisa- } \\
\text { tion }\end{array}$ & $\begin{array}{l}\text { Instant increase fol- } \\
\text { lowed by stabilisa- } \\
\text { tion }\end{array}$ & $\begin{array}{l}\text { Gradual increase fol- } \\
\text { lowed by stabilisa- } \\
\text { tion }\end{array}$ & $\begin{array}{l}\text { Instant increase fol- } \\
\text { lowed by stabilisa- } \\
\text { tion }\end{array}$ & Decrease $^{\mathrm{a}}$ \\
\hline Creatinine & $\begin{array}{l}\text { Instant increase fol- } \\
\text { lowed by stabilisa- } \\
\text { tion }\end{array}$ & $\begin{array}{l}\text { Instant increase fol- } \\
\text { lowed by stabilisa- } \\
\text { tion }\end{array}$ & Increase $^{\mathrm{a}}$ & Increase $^{\mathrm{a}}$ & Increase $^{a}$ \\
\hline
\end{tabular}

$H D L$ high-density lipoprotein, $L D L$ low-density lipoprotein, $N D$ not determined

${ }^{a}$ Detailed changes over the first weeks of treatment with the corresponding drugs were not published

\subsubsection{Serious Infections}

Because JAKinibs simultaneously inhibit signal transduction pathways of several cytokines and growth factors that are relevant to host defence mechanisms, the risk of serious infection is a significant concern for patients treated with these drugs. The incidence rates of serious infections in the CDPs were similar for all JAKinibs except for filgotinib and ranged from 2.5 to 3.8 per 100 PYs [18, 56-58] (Table 5). These values were higher than those of hospitalised infections in the cohorts of patients with RA (1.1-1.6 per 100 PYs) [64] (Supplementary Fig. 4) and similar to those of patients treated with biological DMARDs $[11,65]$. Of note, patients' background of these cohort studies was different from that of clinical trials with JAKinibs. The incidence rates of serious infections in the CDPs of filgotinib was 3.3 per $100 \mathrm{PYs}$ for $100 \mathrm{mg}$ and 1.7 for $200 \mathrm{mg}$ [59], which was within the range of the five RA cohorts (i.e. 1.1-1.6/100 PYs). Integrated data analyses of JAKinibs indicated that the incidence rates of serious infections remained constant with long exposures to these drugs [18, 56-59]. Age is a significant risk factor for serious infections in patients with RA receiving a biological DMARD, but odds ratio of serious infections for biological DMARD use versus non-use are similar between patients under and over 65 years [66]. Taking these results into consideration, announcement of an increased risk of serious and fatal infections in patients aged $>65$ years by The European Medical Agency should be carefully interpreted [67]. The incidence rates of serious infection in the Japanese post-marketing surveillance was 5.38 (4.68-6.15) per 100 PYs [68].

Independent risks of serious infections during treatment with JAKinibs were age, diabetes mellitus, corticosteroid use ( $>=7.5 \mathrm{mg} /$ day of prednisolone), and tofacitinib dosage (10 mg twice daily vs $5 \mathrm{mg}$ twice daily) for tofacitinib [69] and age, non-normal body mass index (vs normal, $18-24 \mathrm{~kg} / \mathrm{m}^{2}$ ), enrolment in the Asian region excluding Japan, and concomitant use of corticosteroids for baricitinib [70].

Rheumatologists should also pay attention to tuberculosis during RA treatment. It is widely recognised that tuberculosis incidence rates are higher in patients with RA compared to the general population [71-73], and these rates (95\% CI) in the five large registries ranged from $0.02(0.01-0.03)$ to $0.35(0.17-0.67)$ [64] (Supplementary Fig. 4). The incidence rate for tuberculosis was 0.2 for tofacitinib and baricitinib and 0 for peficitinib, and three patients receiving upadacitinib were reported to have tuberculosis in the CDP (Table 5). All patients in the RCTs were screened for tuberculosis and excluded from trials if necessary, but probably not all were screened in the registries. Two important observations should be noted. First, incidence rates for tuberculosis during treatment with JAKinibs are strongly associated with the background incidence rates for tuberculosis in a given country or a region [74]. Second, extrapulmonary tuberculosis is more common in patients treated with JAKinibs than in the general population [57, 74], which is similar to characteristics of tuberculosis in patients treated 
Table 5 Safety profiles of JAKinibs

\begin{tabular}{|c|c|c|c|c|c|}
\hline Adverse events & Tofacitinib $[56,62]$ & Baricitinib $[57,63]$ & Upadacitinib [58] & Peficitinib [18] & Filgotinib [59] \\
\hline Serious infection & $2.7(2.5-3.0)$ & 2.8 & $3.8(3.1-4.7)$ & $2.5(1.9-3.2)$ & $\begin{array}{l}100 \mathrm{mg} \mathrm{3.3} \\
200 \mathrm{mg} 1.7\end{array}$ \\
\hline Herpes zoster & $3.9(3.6-4.2)$ & 3.3 & $3.7(3.0-4.5)$ & $6.5(5.5-7.7)$ & $\begin{array}{l}100 \mathrm{mg} \mathrm{1.1} \\
200 \mathrm{mg} 1.7\end{array}$ \\
\hline TB & $0.2(0.1-0.3)$ & 0.2 & 0.1 & 0 & ND \\
\hline $\begin{array}{l}\text { Malignancies excluding } \\
\text { NMSC }\end{array}$ & $0.9(0.8-1.0)$ & 0.8 & $0.9(0.5-1.3)$ & $0.9(0.6-1.3)$ & $\begin{array}{l}100 \mathrm{mg} \mathrm{0.5}, \\
200 \mathrm{mg} 0.5\end{array}$ \\
\hline Lymphoma & $0.1(0.1-0.2)$ & 0.1 & $<0.1$ & $\begin{array}{l}3 \text { cases out of } 1052 \\
\text { patients }^{c}\end{array}$ & ND \\
\hline GI perforation & $0.11(0.07-0.17)$ & $0.04(0.01-0.13)$ & 0.2 & $0.2(0.1-0.5)$ & ND \\
\hline Serious cardiac events & $0.58^{\mathrm{a}}(0.39-0.88)$ & $0.5^{\mathrm{a}}$ & $0.6^{\mathrm{a}}(0.4-1.0)$ & $0.5(0.3-0.9)$ & $\begin{array}{l}100 \mathrm{mg} 0.6^{\mathrm{a}} \\
200 \mathrm{mg} 0.3^{\mathrm{a}}\end{array}$ \\
\hline VTE & ND & 0.5 & $0.6(0.3-1.0)$ & 0 & $\begin{array}{l}100 \mathrm{mg} \mathrm{0.1} \\
200 \mathrm{mg} 0.2\end{array}$ \\
\hline DVT & $0.1(0-0.3)$ & 0.4 & ND & 0 & ND \\
\hline PE & $\begin{array}{l}0.1(0-0.4)^{b} \\
0.2(0-0.4)\end{array}$ & 0.2 & ND & 0 & ND \\
\hline
\end{tabular}

These data show the incidence rates per 100 patient-years (PYs; 95\% CI) except GI perforation (per 1000 PYs). Note that some of the incidence rates of AEs in recently developed JAKinibs are not yet reported in literature. Data are from the integrated safety analyses of each drug. Venous thrombotic events were reported as VTE in upadacitinib and filgotinib, as DVT/PE in tofacitinib, and as VTE/DVT/PE in baricitinib and peficitinib

For upadacitinib, the safety data of patients tested for dosages other than $15 \mathrm{mg}$ (once daily) are not included

$D V T$ deep vein thrombosis, $G I$ gastrointestinal, $N D$ not described, $N M S C$ non-melanoma skin cancer, $P E$ pulmonary embolism, $T B$ tuberculosis, $V T E$ venous thromboembolism

${ }^{a}$ Major adverse cardiovascular event

${ }^{\mathrm{b}} 0.1$ for $5 \mathrm{mg}$ (twice daily) and 0.2 for $10 \mathrm{mg}$ (twice daily)

${ }^{c}$ Each case of diffuse large B-cell lymphoma, lymphoma, and lymphoproliferative disorder

with TNFi. Screening and treatment of latent tuberculosis infections (LTBIs) before starting treatment with a biological DMARD is strongly recommended in clinical settings. A Phase III study of tofacitinib utilised this approach, and of the 286 patients with untreated LTBI, none developed active tuberculosis [74].

A wide range of opportunistic infections has been reported in patients receiving JAKinibs; these include non-tuberculous mycobacterium infections, Cryptococcus infections, Cytomegalovirus infections, Epstein-Barr virus infections, BK virus infections, Pneumocystis pneumonia, aspergillosis, candidiasis, histoplasmosis, paracoccidioidomycosis and toxoplasmosis [75]. Reactivation of hepatitis B virus (HBV) was reported during treatment with JAKinibs [76]. An integrated analysis of tofacitinib with 5671 patients reported 60 opportunistic infections including 34 non-TB infections in Phase II, Phase III, and LTE studies [74] with crude IR (95\% CI) of $0.46(0.36-0.59)$ per 100 PYs.

\subsubsection{Herpes Zoster}

Risks for $\mathrm{HZ}$ in patients with RA receiving tofacitinib, baricitinib, and upadacitinib ranged from 3.3 to 3.9 per 100 PYs
[56-58] (Table 5) and were higher than those previously reported in patients with RA (0.66-1.9 per 100 PYs) [64] (Supplementary Fig. 4). Peficitinib showed a higher incidence rate (95\% CI) of HZ [6.5 (5.5-7.7)] than other JAKinibs because most patients analysed were Japanese [18] who also had a significantly higher incidence of $\mathrm{HZ}$ in association with other JAKinibs [60]. The integrated safety analysis of filgotinib reported an incidence rate of 1.1 per $100 \mathrm{PYs}$ for $100 \mathrm{mg}$ and 1.7 for $200 \mathrm{mg}$ [59]. The risk for HZ in RA patients administered with filgotinib seems to be lower than that of other JAKinibs, but the analysis of a larger database with a more extended observation period is required to draw a conclusion and interpret the differences between filgotinib and other JAKinibs. Risk for HZ in patients receiving a biological DMARD has been reported with hazard ratio (HR) ranging from 1.0 to 1.7 [77].

Asian countries, especially Japan and Korea, had consistently higher incidence rates of $\mathrm{HZ}$ in patients with RA who received JAKinibs in CDPs. The incidence rate (per 100 PYs) of HZ in Japanese and Korean patients who received tofacitinib was 8.0 (6.6-9.6); in Asian patients who received baricitinib it was 5.6, and for peficitinib it was 6.5 (5.5-7.7) $[18,60,61]$. The high incidence rates were confirmed by 
the PMS study of tofacitinib in Japan. The incidence rate of $\mathrm{HZ}$ over 36 months of treatment with tofacitinib in the all-case PMS programme implemented in Japan was 6.81 (6.01-7.68) per 100 PYs [68]. Despite elaborate genetic and epidemiological studies, reasons for this geographic difference are still unknown and require further investigation.

In CDPs, the significant risk factors of developing $\mathrm{HZ}$ were age at baseline [per 10-year increment; HR, 1.41 (95\% CI 1.31-1.52)], corticosteroid dose at baseline [ $>0$ to $\leq 5 \mathrm{mg} /$ day vs $0 \mathrm{mg} /$ day, $1.49(1.22-1.82) ;>5 \mathrm{mg} /$ day vs $0 \mathrm{mg} /$ day, 1.41 (1.12-1.77)], regions of recruitment [Asia vs Western Europe, 2.52 (1.80-3.53); Latin America vs Western Europe, 1.49 (1.03-2.15); and US/Canada/Australia vs Western Europe, 1.43 (1.02-2.02)], smoking status [former smoker or non-smoker vs smoker, 1.32 (1.04-1.69)], and tofacitinib dose during treatment [per $5 \mathrm{mg}$ increment, 1.33 (1.14-1.54)] for tofacitinib [78]. The risk factors of HZ for baricitinib were old age (HR 1.3, 95\% CI 1.17-1.43) and Asian population, especially from Japan, Taiwan, and South Korea (HR 1.82, 95\% CI 1.28-2.58), but the risk of HZ was not increased in the baricitinib programme with the use of corticosteroids [79].

\subsubsection{Malignancy}

Cohort studies demonstrated that patients with RA have a slightly higher risk for overall malignancies than the general population [80]. Patients with RA have an increased standardised incidence rate $(95 \% \mathrm{CI})$ for lymphoma [2.46 (2.05-2.96)] and lung cancer [1.64 (1.51-1.79)] than the general population, whereas a decreased risk of colorectal [0.78 (0.71-0.86)] and breast [0.86 (0.73-1.01)] cancer was reported [80]. Analyses of integrated databases from CDPs indicated no significant effects of JAKinibs on the risk of overall malignancies, excluding non-melanoma skin cancer, in patients with RA compared with the analyses of the five representative cohorts of patients with RA (Table 5 and Supplementary Fig. 4). The incidence rates of overall malignancies were $0.46-0.87$ for the five RA cohorts and 0.5-0.9 for CDPs of JAKinibs [18, 56-61, 81]. No skewed proportion of site-specific malignancies have been reported. Long-term observation in a clinical setting is required to conclude if associations exist between the use of JAKinibs and malignancies.

Two- to three-fold higher risks of lymphoma have been reported in patients with RA, and the risk is associated with accumulated levels of inflammation [82]. In addition, patients with RA sometimes develop iatrogenic immunodeficiency-associated lymphoproliferative disorders (LPDs) $[82,83]$. These are a spectrum of disorders ranging from polymorphic LPDs to typical lymphomas, such as diffuse large B cell lymphoma and Hodgkin lymphoma. Methotrexate and TNFis are examples of drugs causing iatrogenic immunodeficiency-associated LPDs. Some patients developed LPDs during treatment with JAKinibs. Crude incidence rates $(95 \% \mathrm{CI})$ for lymphoma in patients treated with tofacitinib and baricitinib were $0.10(0.06-0.15)$ [56] and 0.10 (95\% CI not reported) [57], respectively. No patients were reported to develop lymphoma in the CDP of peficitinib. The numbers of reported cases with LPDs are few for each JAKinibs. Further accumulation of cases is required to evaluate the risk for LPD precisely.

\subsubsection{Deep Vein Thrombosis (DVT) and Pulmonary Embolism (PE)}

A series of epidemiological studies showed that patients with RA generally have a higher risk for DVT, PE, and venous thromboembolism (VTE) than a control population with risk ratios of 2.08 (95\% CI 1.75-2.47), 2.17 (2.05-2.31), and $1.96(1.81-2.11)$, respectively, according to a meta-analysis [84].

In the analysis of the data from Phase II and Phase III randomised clinical studies of tofacitinib for RA, psoriasis, PsA, and UC [62], the number of reported DVT events was two in patients with RA ( 1 each for $5 \mathrm{mg}$ twice daily and $10 \mathrm{mg}$ twice daily) and one in patients with PsA (10 mg twice daily). There were 5 reported PE events in patients with RA ( $5 \mathrm{mg}$ twice daily, $n=2 ; 10 \mathrm{mg}$ twice daily, $n=3$ ). The incidence rates $(95 \% \mathrm{CI})$ of DVT were $0.1(0.0-0.3)$ for both tofacitinib doses in RA and $0.5(0.0-2.8)$ for $10 \mathrm{mg}$ (twice daily) in PsA, whereas those of PE were $0.1(0.0-0.4)$ for $5 \mathrm{mg}$ (twice daily) and $0.2(0.0-0.4)$ for $10 \mathrm{mg}$ (twice daily). In the placebo-controlled period of clinical trials of baricitinib, five DVT/PE cases, including two serious cases, were reported in the $4 \mathrm{mg}$ baricitinib group, and incidence rates of DVT/PE were 1.2 per 100 PYs in the $4 \mathrm{mg}$ baricitinib group and none in the placebo group [85]. The incidence rates of overall DVT and PE in a combined dataset from the CDP of baricitinib were 0.4 and 0.2 per 100 PYs, respectively [63]. The incidence rates $(95 \% \mathrm{CI})$ of VTE were $0.6(0.3-1.0)$ per $100 \mathrm{PYs}$ for upadacitinib [58], 0.1 for 100 $\mathrm{mg}$ filgotinib, and 0.2 for $200 \mathrm{mg}$ filgotinib [59]. No VTE/ DVT/PE were reported in the CDP of peficitinib. Venous thrombotic events were reported as VTE in upadacitinib and filgotinib, as DVT/PE in tofacitinib, and as VTE/DVT/PE in baricitinib and peficitinib.

A randomised safety endpoint study to compare tofacitinib (CP-690,550-10) at two doses (5 mg and $10 \mathrm{mg}$ twice daily) and TNFi has been implemented (A3921133, NCT02092467), and patients with moderate-to-severe MTXIR RA having at least one cardiovascular risk factor were enrolled. The primary outcome measures were malignancies, excluding NMSC, and incidence of major adverse cardiovascular events (MACE). The FDA found a higher risk of pulmonary embolism in patients with RA treated with $10 \mathrm{mg}$ 
tofacitinib (twice daily) than in patients treated with TNFi, and a higher all-cause mortality in $10 \mathrm{mg}$ tofacitinib (twice daily) versus $5 \mathrm{mg}$ tofacitinib (twice daily) and TNFi groups; thus, a warning for thrombosis was added in the package insert in 2019 [5, 86]. The FDA also stipulated that the drug labelling for baricitinib and upadacitinib mentions the risk for thrombosis [6, 87]. Similarly, the European Medical Agency announced that tofacitinib could increase the risk of blood clots in the lungs and deep veins in patients who are already at high risk [67]. The results of this study have been monitored by an external Rheumatology Drug Safety Monitoring Board, but the events are not yet adjudicated. Appropriateness of incident rates of events in the control arm (i.e. TNFi arm) should be evaluated carefully and precisely. A3921133 is currently still underway, and its final data should frame the results correctly. Continued pharmacovigilance is strongly recommended for JAKinib-related risk of blood clots, since risk for VTE/DVT/PE may be a class effect of JAKinibs.

\subsubsection{Gastrointestinal (GI) Tract Perforation}

A higher risk of GI tract perforation has been described in patients receiving tocilizumab [88-91]. As all JAKinibs inhibit JAK1 and IL-6 signal transduction pathways, the risk of GI tract perforation has been investigated. The incidence rates per 1000 PYs (95\% CI) of GI tract perforation in CDPs for RA treated using JAKinibs were $0.11(0.07-0.17)$ for tofacitinib [56], 0.04 (0.01-0.13) for baricitinib [57], and 0.2 (not reported) for peficitinib [18]. Older age, diverticulitis, other gastrointestinal conditions, and prednisone use (>7.5 mg/day) have been reported as independent risk factors for lower GI tract perforation [91]. These factors, as well as risk factors of acute diverticulitis in general, including presence of diverticulosis, obesity, smoking, diet, lifestyle factors, and use of non-steroidal anti-inflammatory drugs [92] should be carefully evaluated for the risk-benefit balance of treatment before starting treatment with JAKinibs.

\subsubsection{Pregnancy and Breastfeeding}

JAKinibs have been demonstrated to have teratogenic effects in preclinical animal studies $[6,18,87,93]$. The following pregnancy outcomes in 47 patients who received tofacitinib during RCTs were reported: 25 healthy new-borns, one congenital pulmonary valve stenosis, seven spontaneous abortions, eight medical terminations, and six pending or lost to follow-up [94]. JAKinibs are contraindicated during pregnancy, and women of child-bearing age should use effective contraception during and at least 1 week after treatment. Breastfeeding mothers should not use JAKinibs because of the risks to new-borns and infants $[6,18,87,93]$.

\section{Discussion}

\subsection{Implications of Inhibiting JAKs in the Pathogenesis of RA}

All JAKinibs showed good efficacy in MTX-IR patients with moderate-to-severe RA disease activity. In addition, clinical trials of tofacitinib, baricitinib, upadacitinib, and filgotinib demonstrated significant efficacy in biological DMARD-IR and MTX-naïve patients with RA (Figs. 2, 3, and 4, Supplementary Figs 1, 2, and 3). The selectivity to JAKs of each JAKinib differ, but all JAKinibs inhibit JAK1. The selective JAK1 inhibitors, upadacitinib and filgotinib, showed similar efficacy to the other three JAKinibs. These data indicate that JAK1 plays an essential role in RA pathogenesis among the four JAK family members. A novel functional module of the cytokine network, which includes TNF, IL-6, and GM-CSF, has been proposed to explain RA synovitis [95]. Hence, the main targeted pathway of JAKinibs in RA appears to be that of IL-6. The similar efficacy of JAKinibs and tocilizumab reported in MTX-naïve patients with RA [96, 97] may support this hypothesis.

Clinical trials of TNF inhibitors in MTX-naïve patients with RA demonstrated a similar range of efficacy to those of JAKinibs $[98,99]$. Considering that the TNF signal transduction system mainly utilises the NFkB pathway and does not utilise JAK family proteins [100], the pathogenesis of RA synovitis is heterogeneous and includes at least the IL6-JAK1 pathway-dominant type and TNF-NFkB pathwaydominant type, and some patients may present these two types of synovitis simultaneously.

\subsection{Head-to-Head Comparison of JAKinibs and Adalimumab}

Tofacitinib was non-inferior to adalimumab, while baricitinib and upadacitinib were superior as well as non-inferior to adalimumab in MTX-IR patients with RA (Table 2). Biological DMARDs and JAKinib are recommended without preference by the EULAR for RA patients with poor prognostic factors in whom the treatment target could not be achieved with the first csDMARD strategy [9]. The results of head-to-head comparison of JAKinibs and adalimumab in MTX-IR patients with RA indicate possible preference of JAKinibs in terms of clinical efficacy, but long-term safety and pharmacoeconomic consideration are indispensable. Long-term safety data are still in short for upadacitinib and filgotinib, and the results from observational studies using database of regional or national cohorts of patients with RA and claims database may provide further insights. Although baricitinib and upadacitinib showed a better clinical efficacy than adalimumab 
by several measures, pharmacoeconomic implication of the difference is not clear. Accumulation of evidence is still needed for appropriate positioning of JAKinibs in RA treatment strategies.

\subsection{Difference in the Incidence Rates of $\mathrm{HZ}$ Following JAKinib Treatment}

The increased risk of $\mathrm{HZ}$ has been recognised as a common adverse drug reaction in patients administered JAKinibs. Although PY are still few, the incidence rate of $\mathrm{HZ}$ in the CDP of filgotinib was 1.1 per $100 \mathrm{PYs}$ for $100 \mathrm{mg}$ and 1.7 per 100PYs for $200 \mathrm{mg}$ [59] and was within the range of incidence rates from the three representative RA cohorts (i.e. CORRNA, IORRA, and CORRONA International) (Table 5 and Supplementary Fig. 4). Furthermore, another JAK1 inhibitor, upadacitinib, exhibited an incidence rate of 3.7 (95\% CI 3.0-4.5), which is very close to the value associated with tofacitinib (JAK1/3 inhibitor) or baricitinib (JAK1/2 inhibitor) (Table 5). Because all JAKinibs target the conserved ATP-binding pockets of JAKs, JAKinibs are relatively but not absolutely selective to JAK family proteins and may exert unintended inhibition depending on drug concentrations in vivo. Effects of JAKinibs at clinical doses on IL-15-induced NK cell proliferation, which is mediated via JAK3, have been reported [101]. Filgotinib showed less inhibition than other JAKinibs on the JAK1-mediated signaling of IFN-gamma and IL-2, 4 and 15 [102]. Lower calculated inhibition of IL-15-induced NK cell proliferation and of interferon-gamma signaling with filgotinib versus other JAKinibs may explain the differences in the incidence rates of $\mathrm{HZ}$ observed with these JAKinibs, but results from long-term observational studies are required to discuss and confirm the differences.

\subsection{Safety Management of JAKinibs in Patients with RA and Other IMIDs}

During the past two decades, evidence on the safety of biological DMARDs has been accumulated, and proper screening and monitoring methods are established in accordance with recommendations or guidelines of countries or regions $[9,103]$. Considering the mechanism of action of JAKinibs, it is reasonable and highly recommended to follow the screening and monitoring methods for biological DMARDs when a physician prescribes JAKinibs to patients.

Before starting treatment with a JAKinib, risks of serious infection, HZ, tuberculosis, malignancy, GI perforation, serious cardiac events, and thromboembolic events should be evaluated by obtaining data from history, physical examination, laboratory tests, and imaging tests. History of malignancy, diverticulitis and thromboembolic events will be useful for evaluating the risks of a JAKinib in each patient. Regarding the risks associated with serious infections; age, comorbidities including diabetes mellitus and chronic respiratory diseases, the use of glucocorticoids, and recent hospitalised infection or serious infection are especially important [104-107]. In addition to complete blood counts and laboratory tests for liver and kidney function, hepatitis B (HBs) antigen, HBc antibody, HBs antibody, $\mathrm{HCV}$ antibody, and $\beta$-D-glucan should be evaluated. In HBs antigen-positive patients or HBs antigen-negative and $\mathrm{HBc}$ or HBs antibody-positive patients (i.e. patients with previous HBV infections), measuring levels of HBV-DNA and adhering to local guidelines are recommended [76]. History of exposure to Mycobacterium tuberculosis, chest X-rays, and interferon- $\gamma$-releasing assays are required to identify patients with LTBIs.

After starting treatment with a JAKinib, complete blood count and laboratory tests for liver and kidney function should be performed regularly, and doses should be adjusted if necessary. Effectiveness of treatment is evaluated using composite measures, such as simplified disease activity index and clinical disease activity index, health assessment questionnaires, and imaging tests such as X-rays and sonography of affected joints [9]. The monitoring of signs and symptoms of AEs of special interest, as listed in Table 5, is strongly recommended.

In conclusion, JAKinibs are efficacious for RA and other immune-mediated inflammatory diseases. Selectivity of JAKinibs to JAK family protein depends on drug concentration in vivo. JAK inhibitors with different selectivity to JAK family proteins have similar efficacy and safety profiles, with some minor differences in patients with RA. Long-term observational studies enrolling patients with diverse clinical backgrounds are required to strike a risk-benefit balance in clinical settings.

Acknowledgements We would like to thank Editage (www.edita ge.com) for English language editing.

Author contributions $\mathrm{MH}$ and $\mathrm{SH}$ designed the study and extracted and interpreted evidence for this manuscript. MH drafted the manuscript, and $\mathrm{MH}$ and SH revised it critically for important intellectual content and gave final approval for submission.

Availability of data and material Not applicable.

Code availability Not applicable.

\section{Compliance with Ethical Standards}

Funding This work was supported by a research grant from the Ministry of Health, Labour, and Welfare (H30-menneki-shitei-002).

Conflicts of interest $\mathrm{MH}$ has received research grants from AbbVie Japan GK, Asahi Kasei Corp., Astellas Pharma Inc., Ayumi Pharma- 
ceutical Co., Bristol Myers Squibb Co., Ltd., Chugai Pharmaceutical Co., Daiichi-Sankyo, Inc., Eisai Co., Ltd., Kissei Pharmaceutical Co., Ltd., Mitsubishi Tanabe Pharma Co., Nippon Kayaku Co., Ltd., Sekiui Medical, Shionogi \& Co., Ltd., Taisho Pharmaceutical Co., Ltd., Takeda Pharmaceutical Co., Ltd., and Teijin Pharma Ltd; has received speaker's fees from AbbVie Japan GK, Ayumi Pharmaceutical Co., Boehringer-Ingelheim Japan, Inc., Bristol Myers Squibb Co., Ltd., Chugai Pharmaceutical Co., Ltd., Eisai Co., Ltd., Eli Lilly Japan K.K., GlaxoSmithKline K.K., Kissei Pharmaceutical Co., Ltd., Pfizer Japan Inc., Takeda Pharmaceutical Co., Ltd., and Teijin Pharma Ltd; and is a consultant for AbbVie, Boehringer-Ingelheim, Bristol Myers Squibb Co., Kissei Pharmaceutical Co., Ltd., and Teijin Pharma. SH has nothing to declare.

Ethics approval Not applicable.

Consent to participate Not applicable.

Consent for publication Not applicable.

Open Access This article is licensed under a Creative Commons Attribution-NonCommercial 4.0 International License, which permits any non-commercial use, sharing, adaptation, distribution and reproduction in any medium or format, as long as you give appropriate credit to the original author(s) and the source, provide a link to the Creative Commons licence, and indicate if changes were made. The images or other third party material in this article are included in the article's Creative Commons licence, unless indicated otherwise in a credit line to the material. If material is not included in the article's Creative Commons licence and your intended use is not permitted by statutory regulation or exceeds the permitted use, you will need to obtain permission directly from the copyright holder. To view a copy of this licence, visit http://creativecommons.org/licenses/by-nc/4.0/.

\section{References}

1. Villarino AV, Kanno Y, O'Shea JJ. Mechanisms and consequences of Jak-STAT signaling in the immune system. Nat Immunol. 2017;18:374-84.

2. Morris R, Kershaw NJ, Babon JJ. The molecular details of cytokine signaling via the JAK/STAT pathway. Protein Sci. 2018;27:1984-2009.

3. Ghoreschi K, Laurence A, O'Shea JJ. Janus kinases in immune cell signaling. Immunol Rev. 2009;228:273-87.

4. Kanai T, Jenks J, Nadeau KC. The STAT5b pathway defect and autoimmunity. Front Immunol. 2012;3:234.

5. Pfizer Labs. Highlights of prescribing information of Xeljanz/ Xeljanz XR (tofacitinib). https://www.accessdata.fda.gov/ drugsatfda_docs/label/2018/203214s018lbl.pdf. Accessed 20 Feb 2020.

6. AbbVie Biotechnology Ltd. Highlights of prescribing infromation of RINVOQ (upadacitinib). https://www.accessdata.fda. gov/drugsatfda_docs/label/2019/211675s000lbl.pdf. Accessed 20 Feb 2020.

7. Elli Lilly and Company. Japanese package inserts of baricitinib (in Japanese). http://www.info.pmda.go.jp/go/pack/39990 43F1020_1_02/. Accessed 20 Feb 2020.

8. Astellas. Japanese package insert of peficitinib (in Japanese). https://www.kegg.jp/medicus-bin/japic_med?japic code $=00068023$. Accessed $20 \mathrm{Feb} 2020$.

9. Smolen JS, Landewe RBM, Bijlsma JWJ, Burmester GR, Dougados M, Kerschbaumer A, et al. EULAR recommendations for the management of rheumatoid arthritis with synthetic and biological disease-modifying antirheumatic drugs: 2019 update. Ann Rheum Dis. 2020;79:685-99.

10. Kerschbaumer A, Sepriano A, Smolen JS, van der Heijde D, Dougados M, van Vollenhoven R, et al. Efficacy of pharmacological treatment in rheumatoid arthritis: a systematic literature research informing the 2019 update of the EULAR recommendations for management of rheumatoid arthritis. Ann Rheum Dis. 2020;79:744-59.

11. Sepriano A, Kerschbaumer A, Smolen JS, van der Heijde D, Dougados M, van Vollenhoven R, et al. Safety of synthetic and biological DMARDs: a systematic literature review informing the 2019 update of the EULAR recommendations for the management of rheumatoid arthritis. Ann Rheum Dis. 2020;79:760-70.

12. Anniina VT, Haikarainen T, Raivola J, Silvennoinen O. Selective JAKinibs: prospects in inflammatory and autoimmune diseases. BioDrugs. 2019;33:15-32.

13. Europe Medical Agency. Summary of product characteristics of XELJANZ. https://www.ema.europa.eu/en/documents/ product-information/xeljanz-epar-product-information_en.pdf. Accessed 20 Feb 2020

14. Europe Medical Agency. Summary of product characteristics of OLUMIANT. https://www.ema.europa.eu/en/documents/produ ct-information/olumiant-epar-product-information_en.pdf. Accessed 20 Feb 2020.

15. Pharmaceutical and Medical Devices Agency. Pharmaceutical and Medical Devices Agency Report on the Deliberation Results. Olumiant Tablets $4 \mathrm{mg}$, Olumiant Tablets $2 \mathrm{mg}$. http://www.pmda.go.jp/drugs/2017/P20170724002/53047 1000_22900AMX00582_A100_1.pdf. Accessed 20 Feb 2020.

16. Europe Medical Agency. Summary of product characteristics of RINVOQ. https://www.ema.europa.eu/en/documents/productinformation/rinvoq-epar-product-information_en.pdf. Accessed 20 Feb 2020.

17. Pharmaceutical and Medical Devices Agency. Pharmaceutical and Medical Devices Agency Report on the Deliberation Results. Rinvoq Tablets $15 \mathrm{mg}$, Rinvoq Tablets $7.5 \mathrm{mg}$. . http:// www.pmda.go.jp/drugs/2020/P20200120001/112130000_30200 AMX00027_A100_1.pdf). Accessed 02 Aug 2020.

18. Pharmaceutical and Medical Devices Agency. Pharmaceutical and Medical Devices Agency Report on the Deliberation Results. Smyraf Tablets $100 \mathrm{mg}$, Smyraf Tablets $50 \mathrm{mg}$. https:// www.pmda.go.jp/drugs/2019/P20190419003/800126000_23100 AMX00285_A100_1.pdf Accessed 20 Feb 2020.

19. Florence N, Fagard L, Van der Aa A, Harrison P, Xin Y, Tasset C. Influence of age and renal impairment on the steady state pharmacokinetics of filgotinib, a selective JAK1 inhibitor. Br J Clin Pharmacol. 2018;84:2779-89.

20. Florence N, Vayssière B, Galien R, Fagard L, Van der Aa A, Goss S, et al. Filgotinib (GLPG0634), a selective JAK1 inhibitor, shows similar pharmacokinetics and pharmacodynamics profiles in Japanese and caucasian healthy volunteers [abstract number 2763]. Arthritis Rheumatol. 2015;67.

21. Gilead Sciences I. A randomized, double-blind, placebo-controlled, multicenter, Phase II proof-of-concept study to evaluate safety, tolerability, and efficacy of GS-9876 in subjects with active rheumatoid althritis on background therapy with methotrexate. https://clinicaltrials.gov/ProvidedDocs/81/NCT0288518 1/Prot_001.pdf. Accessed 20 Feb 2020.

22. van der Heijde D, Tanaka Y, Fleischmann R, Keystone E, Kremer J, Zerbini C, et al. Tofacitinib (CP-690,550) in patients with rheumatoid arthritis receiving methotrexate: twelve-month data from a twenty-four-month phase III randomized radiographic study. Arthritis Rheum. 2013;65:559-70. 
23. Taylor PC, Keystone EC, van der Heijde D, Weinblatt ME, Del Carmen Morales L, Reyes Gonzaga J, et al. Baricitinib versus placebo or adalimumab in rheumatoid arthritis. N Engl J Med. 2017;376:652-62.

24. Takeuchi T, Tanaka Y, Tanaka S, Kawakami A, Iwasaki M, Katayama K, et al. Efficacy and safety of peficitinib (ASP015K) in patients with rheumatoid arthritis and an inadequate response to methotrexate: results of a phase III randomised, double-blind, placebo-controlled trial (RAJ4) in Japan. Ann Rheum Dis. 2019;78:1305-19.

25. Fleischmann R, Pangan AL, Song IH, Mysler E, Bessette L, Peterfy $\mathrm{C}$, et al. Upadacitinib versus placebo or adalimumab in patients with rheumatoid arthritis and an inadequate response to methotrexate: results of a phase III, double-blind, randomized controlled trial. Arthritis Rheumatol. 2019;71:1788-800.

26. Combe B, Kivitz A, Tanaka Y, Heijde DVD, Matzkies F, Bartok B, et al. LB0001 efficacy and safety of filgotinib for patients with rheumatoid arthritis with inadequate response to methotrexate: FINCH1 primary outcome results. Ann Rheum Dis. 2019;78:77-8.

27. Dougados M, van der Heijde D, Chen YC, Greenwald M, Drescher E, Liu J, et al. Baricitinib in patients with inadequate response or intolerance to conventional synthetic DMARDs: results from the RA-BUILD study. Ann Rheum Dis. 2017;76:88-95.

28. Burmester GR, Blanco R, Charles-Schoeman C, Wollenhaupt J, Zerbini C, Benda B, et al. Tofacitinib (CP-690,550) in combination with methotrexate in patients with active rheumatoid arthritis with an inadequate response to tumour necrosis factor inhibitors: a randomised phase 3 trial. Lancet. 2013;381:451-60.

29. Genovese MC, Kremer J, Zamani O, Ludivico C, Krogulec M, Xie L, et al. Baricitinib in patients with refractory rheumatoid arthritis. N Engl J Med. 2016;374:1243-52.

30. Genovese MC, Fleischmann R, Combe B, Hall S, RubbertRoth A, Zhang Y, et al. Safety and efficacy of upadacitinib in patients with active rheumatoid arthritis refractory to biologic disease-modifying anti-rheumatic drugs (SELECT-BEYOND): a double-blind, randomised controlled phase 3 trial. Lancet. 2018;391:2513-24.

31. Genovese MC, Kalunian K, Gottenberg JE, Mozaffarian N, Bartok B, Matzkies F, et al. Effect of filgotinib vs placebo on clinical response in patients with moderate to severe rheumatoid arthritis refractory to disease-modifying antirheumatic drug therapy: the FINCH 2 randomized clinical trial. JAMA. 2019;322:315-25.

32. Lee EB, Fleischmann R, Hall S, Wilkinson B, Bradley JD, Gruben D, et al. Tofacitinib versus methotrexate in rheumatoid arthritis. N Engl J Med. 2014;370:2377-86.

33. Fleischmann R, Schiff M, van der Heijde D, Ramos-Remus C, Spindler A, Stanislav M, et al. Baricitinib, methotrexate, or combination in patients with rheumatoid arthritis and no or limited prior disease-modifying antirheumatic drug treatment. Arthritis Rheumatol. 2017;69:506-17.

34. Vollenhoven RV, Takeuchi T, Pangan A, Friedman A, Chen S, Rischmueller M, et al. THU0197 monotherapy with upadacitinib in MTX-naïve patients with rheumatoid arthritis: results at 48 weeks from the select-early study. Ann Rheum Dis. 2019;78:376-7.

35. Westhovens R, Rigby W, van der Heijde D, Ching D, Bartok B, Matzkies F, et al. LB0003 efficacy and safety of filgotinib for patients with rheumatoid arthritis naïve to methotrexate therapy: FINCH3 primary outcome results. Ann Rheum Dis. 2019;78:259-61.

36. Fleischmann R, Mysler E, Hall S, Kivitz AJ, Moots RJ, Luo $\mathrm{Z}$, et al. Efficacy and safety of tofacitinib monotherapy, tofacitinib with methotrexate, and adalimumab with methotrexate in patients with rheumatoid arthritis (ORAL Strategy): a phase 3b/4, double-blind, head-to-head, randomised controlled trial. Lancet. 2017;390:457-68.

37. U.S. National Library of Medicine. ClinicalTrials.gov. https:// clinicaltrials.gov/. Accessed 8 May 2020.

38. Pfizer. Japanese package inserts of tofacitinib (in Japanese). https ://www.info.pmda.go.jp/go/pack/3999034F1020_1_13/\%3Fvie w\%3Dframe\%26style\%3DXML\%26lang\%3Dja. Accessed 20 Feb 2020.

39. Mease P, Hall S, FitzGerald O, van der Heijde D, Merola JF, Avila-Zapata F, et al. Tofacitinib or adalimumab versus placebo for psoriatic arthritis. N Engl J Med. 2017;377:1537-50.

40. Gladman D, Rigby W, Azevedo VF, Behrens F, Blanco R, Kaszuba A, et al. Tofacitinib for Psoriatic arthritis in patients with an inadequate response to TNF inhibitors. N Engl J Med. 2017;377:1525-36.

41. Mease P, Coates LC, Helliwell PS, Stanislavchuk M, RychlewskaHanczewska A, Dudek A, et al. Efficacy and safety of filgotinib, a selective Janus kinase 1 inhibitor, in patients with active psoriatic arthritis (EQUATOR): results from a randomised, placebocontrolled, phase 2 trial. Lancet. 2018;392:2367-77.

42. Panes J, Sandborn WJ, Schreiber S, Sands BE, Vermeire S, D'Haens G, et al. Tofacitinib for induction and maintenance therapy of Crohn's disease: results of two phase IIb randomised placebo-controlled trials. Gut. 2017;66:1049-59.

43. Vermeire S, Schreiber S, Petryka R, Kuehbacher T, Hebuterne $\mathrm{X}$, Roblin X, et al. Clinical remission in patients with moderateto-severe Crohn's disease treated with filgotinib (the FITZROY study): results from a phase 2 , double-blind, randomised, placebo-controlled trial. Lancet. 2017;389:266-75.

44. Sandborn WJ, Feagan BG, Loftus EV Jr, Peyrin-Biroulet L, Van Assche G, D'Haens G, et al. Efficacy and safety of upadacitinib in a randomized trial of patients with Crohn's disease. Gastroenterology. 2020;158(8):2123-2138.e8. https://doi.org/10.1053/j. gastro.2020.01.047.

45. Wallace DJ, Furie RA, Tanaka Y, Kalunian KC, Mosca M, Petri MA, et al. Baricitinib for systemic lupus erythematosus: a double-blind, randomised, placebo-controlled, phase 2 trial. Lancet. 2018;392:222-31.

46. van der Heijde D, Deodhar A, Wei JC, Drescher E, Fleishaker D, Hendrikx T, et al. Tofacitinib in patients with ankylosing spondylitis: a phase II, 16-week, randomised, placebo-controlled, doseranging study. Ann Rheum Dis. 2017;76:1340-7.

47. van der Heijde D, Baraliakos X, Gensler LS, Maksymowych WP, Tseluyko V, Nadashkevich O, et al. Efficacy and safety of filgotinib, a selective Janus kinase 1 inhibitor, in patients with active ankylosing spondylitis (TORTUGA): results from a randomised, placebo-controlled, phase 2 trial. Lancet. 2018;392:2378-87.

48. van der Heijde D, Song IH, Pangan AL, Deodhar A, van den Bosch F, Maksymowych WP, et al. Efficacy and safety of upadacitinib in patients with active ankylosing spondylitis (SELECTAXIS 1): a multicentre, randomised, double-blind, placebocontrolled, phase 2/3 trial. Lancet. 2019;394:2108-17.

49. Wollenhaupt J, Lee E-B, Curtis JR, Silverfield J, Terry K, Soma $\mathrm{K}$, et al. Safety and efficacy of tofacitinib for up to 9.5 years in the treatment of rheumatoid arthritis: final results of a global, openlabel, long-term extension study. Arthritis Res Ther. 2019;21:89.

50. Yamanaka H, Tanaka Y, Takeuchi T, Sugiyama N, Yuasa H, Toyoizumi S, et al. Tofacitinib, an oral Janus kinase inhibitor, as monotherapy or with background methotrexate, in Japanese patients with rheumatoid arthritis: an open-label, long-term extension study. Arthritis Res Ther. 2016;18:34.

51. Smolen JS, Genovese MC, Takeuchi T, Hyslop DL, Macias WL, Rooney T, et al. Safety profile of baricitinib in patients with active rheumatoid arthritis with over 2 years median time in treatment. J Rheumatol. 2019;46:7-18. 
52. Tanaka Y, Takeuchi T, Tanaka S, Kawakami A, Iwasaki M, Song YW, et al. Efficacy and safety of peficitinib (ASP015K) in patients with rheumatoid arthritis and an inadequate response to conventional DMARDs: a randomised, double-blind, placebo-controlled phase III trial (RAJ3). Ann Rheum Dis. 2019;78:1320-32.

53. Fleischmann RM, Genovese MC, Enejosa JV, Mysler E, Bessette L, Peterfy C, et al. Safety and effectiveness of upadacitinib or adalimumab plus methotrexate in patients with rheumatoid arthritis over 48 weeks with switch to alternate therapy in patients with insufficient response. Ann Rheum Dis. 2019;78:1454-62.

54. Galien R, Harrison P, Brys R, Van der Aa A, van 't Klooster G, Tasset C. 4-Week Treatment of Rheumatoid Arthritis Patients with the JAK1-Selective Inhibitor Filgotinib (GLPG0634) Changes Lipid Profile with a Preferential Increase in HDL [abstract number 1681]. 2015;67(suppl 10).

55. Westhovens R, Taylor PC, Alten R, Pavlova D, Enriquez-Sosa F, Mazur M, et al. Filgotinib (GLPG0634/GS-6034), an oral JAK1 selective inhibitor, is effective in combination with methotrexate (MTX) in patients with active rheumatoid arthritis and insufficient response to MTX: results from a randomised, dose-finding study (DARWIN 1). Ann Rheum Dis. 2017;76:998-1008.

56. Cohen SB, Tanaka Y, Mariette X, Curtis JR, Lee EB, Nash P, et al. Long-term safety of tofacitinib for the treatment of rheumatoid arthritis up to 8.5 years: integrated analysis of data from the global clinical trials. Ann Rheum Dis. 2017;76:1253-62.

57. Genovese MC, Smolen JS, Takeuchi T, Burmester GR, Brinker D, Rooney T, et al. THU0078 safety profile of baricitinib for the treatment of rheumatoid arthritis up to 7 years: an updated integrated safety analysiS. Ann Rheum Dis. 2019;78:308-9.

58. Cohen SB, Vollenhoven RV, Winthrop K, Zerbini C, Tanaka Y, Bessette L, et al. THU0167 safety profile of upadacitinib in rheumatoid arthritis: integrated analysis from the select phase 3 clinical program. Ann Rheum Dis. 2019;78:357.

59. Genovese MC, Winthrop K, Tanaka Y, Takeuchi T, Kivitz A, Matzkies F, et al. THU0202 integrated safety analysis of filgotinib treatment forrheumatoid arthritis from 7 clinical trials. Ann Rheu Dis. 2020;79:324-5.

60. Harigai M. Growing evidence of the safety of JAK inhibitors in patients with rheumatoid arthritis. Rheumatology (Oxford, England). 2019;58:i34-42.

61. Honda S, Harigai M. Safety of baricitinib in patients with rheumatoid arthritis. Expert Opin Drug Saf. 2020;19(5):545-51.

62. Mease PJ, Kremer J, Cohen S, Curtis JR, Charles-Schoeman $\mathrm{C}$, Loftus EV, et al. Incidence of thromboembolic events in the tofacitinib rheumatoid arthritis, psoriasis, psoriatic arthritis and ulcerative colitis development programs [abstract number 16L]. Arthritis Rheumatol. 2017;69 (suppl 10).

63. Taylor PC, Weinblatt ME, Burmester GR, Rooney TP, Witt $\mathrm{S}$, Walls $\mathrm{CD}$, et al. Cardiovascular safety during treatment with baricitinib in rheumatoid arthritis. Arthritis Rheumatol. 2019;71:1042-55.

64. Yamanaka H, Askling J, Berglind N, Franzen S, Frisell T, Garwood $\mathrm{C}$, et al. Infection rates in patients from five rheumatoid arthritis (RA) registries: contextualising an RA clinical trial programme. RMD Open. 2017;3:e00498.

65. Rose-John S, Winthrop K, Calabrese L. The role of IL-6 in host defence against infections: immunobiology and clinical implications. Nat Rev Rheumatol. 2017;13:399-409.

66. Sugihara T, Harigai M. Targeting low disease activity in elderly-onset rheumatoid arthritis: current and future roles of biological disease-modifying antirheumatic drugs. Drugs Aging. 2016;33:97-107.

67. Europe Medical Agency. EMA confirms Xeljanz to be used with caution in patients at high risk of blood clots. https://www.ema. europa.eu/documents/referral/xeljanz-article-20-procedure-emaconfirms-xeljanz-be-used-caution-patients-high-risk-blood-clots _en.pdf. Accessed 20 Feb 2020.

68. Tamura N, Kuwana M, Atsumi T, Takei S, Harigai M, Fujii $\mathrm{T}$, et al. Infection events in Japanese patients with rheumatoid arthritis treated with tofacitinib: interim all-case post-marketing surveillance [abstract number 1516]. Arthritis Rheumatol. 2018;70 (suppl 10).

69. Cohen S, Radominski SC, Gomez-Reino JJ, Wang L, Krishnaswami S, Wood SP, et al. Analysis of infections and all-cause mortality in phase II, phase III, and long-term extension studies of tofacitinib in patients with rheumatoid arthritis. Arthritis Rheumatol. 2014;66:2924-37.

70. Winthrop K, Genovese M, Harigai M, Chen L, Dickson C, Hyslop D, et al. Serious infection and associated risk factors in patients with moderate to severe rheumatoid arthritis treated with baricitinib (OP0248). Ann Rheum Dis. 2017;76:158.

71. Yamada T, Nakajima A, Inoue E, Tanaka E, Hara M, Tomatsu T, et al. Increased risk of tuberculosis in patients with rheumatoid arthritis in Japan. Ann Rheum Dis. 2006;65:1661-3.

72. Askling J, Fored CM, Brandt L, Baecklund E, Bertilsson L, Coster $\mathrm{L}$, et al. Risk and case characteristics of tuberculosis in rheumatoid arthritis associated with tumor necrosis factor antagonists in Sweden. Arthritis Rheum. 2005;52:1986-92.

73. Winthrop KL. Risk and prevention of tuberculosis and other serious opportunistic infections associated with the inhibition of tumor necrosis factor. Nat Clin Pract. 2006;2:602-10.

74. Winthrop KL, Park SH, Gul A, Cardiel MH, Gomez-Reino JJ, Tanaka Y, et al. Tuberculosis and other opportunistic infections in tofacitinib-treated patients with rheumatoid arthritis. Ann Rheum Dis. 2016;75:1133-8.

75. Harigai M. Growing evidence of the safety of JAK inhibitors in patients with rheumatoid arthritis. Rheumatology (Oxford). 2019;58(Suppl 1):i34-42. https://doi.org/10.1093/rheumatology/ key287.

76. Harigai M, Winthrop K, Takeuchi T, Hsieh T-Y, Chen Y-M, Smolen JS, et al. An evaluation of hepatitis B virus in clinical trials of baricitinib in rheumatoid arthritis. RMD Open. 2020;6(1):e001095. https://doi.org/10.1136/rmdopen-2019-001095.

77. Ramiro S, Sepriano A, Chatzidionysiou K, Nam JL, Smolen JS, van der Heijde D, et al. Safety of synthetic and biological DMARDs: a systematic literature review informing the 2016 update of the EULAR recommendations for management of rheumatoid arthritis. Ann Rheum Dis. 2017;76:1101-36.

78. Winthrop KL, Curtis JR, Lindsey S, Tanaka Y, Yamaoka K, Valdez $\mathrm{H}$, et al. Herpes zoster and tofacitinib: clinical outcomes and the risk of concomitant therapy. Arthritis Rheumatol. 2017;69:1960-8.

79. Chen Y-H, Chen Y-M, Smolen JS, Takeuchi T, Muller R, Walker $\mathrm{D}$, et al. FRI0164 incidence rate and characterization of herpes zoster in patients with moderate-to-severe rheumatoid arthritis: an update from baricitinib clinical studies. Ann Rheum Dis. 2019;78:755.

80. Simon TA, Thompson A, Gandhi KK, Hochberg MC, Suissa $\mathrm{S}$. Incidence of malignancy in adult patients with rheumatoid arthritis: a meta-analysis. Arthritis Res Ther. 2015;17:212.

81. Askling J, Berglind N, Franzen S, Frisell T, Garwood C, Greenberg JD, et al. How comparable are rates of malignancies in patients with rheumatoid arthritis across the world? A comparison of cancer rates, and means to optimise their comparability, in five RA registries. Ann Rheum Dis. 2016;75:1789-96.

82. Harigai M. Lymphoproliferative disorders in patients with rheumatoid arthritis in the era of widespread use of methotrexate: a review of the literature and current perspective. Mod Rheumatol. 2018;28:1-8. 
83. World Health Organization. Immunodeficiency-associated lymphoproliferative disorders. In: Swerdlow SH, Campo E, Harris NL, Jaffe ES, Pileri SA, Stein H, et al., editors. WHO Classification of Tumours of Haematopoietic and Lymphoid Tissues. Lyon: The International Agency for Research on Cancer (IRAC); 2017. p. $444-82$.

84. Ungprasert P, Srivali N, Spanuchart I, Thongprayoon C, Knight EL. Risk of venous thromboembolism in patients with rheumatoid arthritis: a systematic review and meta-analysis. Clin Rheumatol. 2014;33:297-304.

85. Kremer J, Huizinga TWJ, Chen L, Saifan CG, Issa M, Witt SL, et al. Analysis of neutrophils, lymphocytes, and platelets in pooled phase 2 and phase 3 studies of baricitinib for rheumatoid arthritis (FRI0090). Ann Rheum Dis. 2017;76:512.

86. U.S. Food \& Drug Administration. FDA approves Boxed Warning about increased risk of blood clots and death with higher dose of arthritis and ulcerative colitis medicine tofacitinib (Xeljanz, Xeljanz XR). https://www.fda.gov/drugs/drug-safety-and-avail ability/fda-approves-boxed-warning-about-increased-risk-blood -clots-and-death-higher-dose-arthritis-and. Accessed 20 Feb 2020.

87. Eli Lilly and Company. Highlights of prescribing information of OLUMINANT (baricitinib) tablets. http://pi.lilly.com/us/olumi ant-uspi.pdf. Accessed 20 Feb 2020.

88. Yamamoto K, Goto H, Hirao K, Nakajima A, Origasa H, Tanaka $\mathrm{K}$, et al. Longterm safety of tocilizumab: results from 3 years of followup postmarketing surveillance of 5573 patients with rheumatoid arthritis in Japan. J Rheumatol. 2015;42:1368-75.

89. Koike T, Harigai M, Inokuma S, Ishiguro N, Ryu J, Takeuchi $\mathrm{T}$, et al. Effectiveness and safety of tocilizumab: postmarketing surveillance of 7901 patients with rheumatoid arthritis in Japan. J Rheumatol. 2014;41:15-23.

90. Schiff MH, Kremer JM, Jahreis A, Vernon E, Isaacs JD, van Vollenhoven RF. Integrated safety in tocilizumab clinical trials. Arthritis Res Ther. 2011;13:R141.

91. Xie F, Yun H, Bernatsky S, Curtis JR. Risk of gastrointestinal perforation among rheumatoid arthritis patients receiving tofacitinib, tocilizumab, or other biologic treatments. Arthritis Rheumatol. 2016;68:2612-7.

92. Swanson SM, Strate LL. Acute colonic diverticulitis. Ann Intern Med. 2018;168:ITC65-80.

93. Pfizer Inc. Xeljanz, Highlights of prescribing information2018; (January 29). http://labeling.pfizer.com/ShowLabeli ng.aspx?id=959\#section-8.1. Accessed 16 July 2018 .

94. Clowse ME, Feldman SR, Isaacs JD, Kimball AB, Strand V, Warren RB, et al. Pregnancy outcomes in the tofacitinib safety databases for rheumatoid arthritis and psoriasis. Drug Saf. 2016;39:755-62.

95. McInnes IB, Buckley CD, Isaacs JD. Cytokines in rheumatoid arthritis-shaping the immunological landscape. Nat. Rev. Rheumatol. 2016;12:63-8.
96. Burmester GR, Rigby WF, van Vollenhoven RF, Kay J, RubbertRoth A, Kelman A, et al. Tocilizumab in early progressive rheumatoid arthritis: FUNCTION, a randomised controlled trial. Ann Rheum Dis. 2016;75:1081-91.

97. Bijlsma JWJ, Welsing PMJ, Woodworth TG, Middelink LM, Pethö-Schramm A, Bernasconi C, et al. Early rheumatoid arthritis treated with tocilizumab, methotrexate, or their combination (U-Act-Early): a multicentre, randomised, doubleblind, double-dummy, strategy trial. Lancet (London, England). 2016;388:343-55.

98. Smolen JS, Aletaha D. Rheumatoid arthritis therapy reappraisal: strategies, opportunities and challenges. Nat Rev Rheumatol. 2015;11:276-89.

99. Burmester GR, Pope JE. Novel treatment strategies in rheumatoid arthritis. Lancet (London, England). 2017;389:2338-48.

100. Varfolomeev E, Vucic D. Intracellular regulation of TNF activity in health and disease. Cytokine. 2018;101:26-32.

101. Di Paolo J, Downie B, Meng A, Mollova N, Yu Y, Han P. Evaluation of potential mechanisms underlying the safety observations of filgotinib in clinical studies in RA [abstract number 59]. Arthritis Rheumatol. 2019;71 (suppl 10).

102. Traves PG, Murray B, Campigotto F, Meng A, Di Paolo J. THU0067 JAK selectivity and the impact oncytokine signaling inhibition at clinical rheumatoid arthritis doses. Ann Rheum Dis. 2020;79:246

103. Singh JA, Saag KG, Bridges SL Jr, Akl EA, Bannuru RR, Sullivan MC, et al. 2015 American College of Rheumatology Guideline for the Treatment of Rheumatoid Arthritis. Arthritis Rheumatol. (Hoboken, NJ). 2016;68:1-26.

104. Crowson CS, Hoganson DD, Fitz-Gibbon PD, Matteson EL. Development and validation of a risk score for serious infection in patients with rheumatoid arthritis. Arthritis Rheum. 2012;64:2847-55.

105. Yamazaki H, Sakai R, Koike R, Miyazaki Y, Tanaka M, Nanki $\mathrm{T}$, et al. Assessment of risks for pulmonary infection during 12 months after commencing or intensifying immunosuppressive treatment for active connective tissue diseases: a report from a large-scale prospective cohort study. J Rheumatol. 2014;25:609-14.

106. Zink A, Manger B, Kaufmann J, Eisterhues C, Krause A, Listing $\mathrm{J}$, et al. Evaluation of the RABBIT Risk Score for serious infections. Ann Rheum Dis. 2014;73:1673-6.

107. Tanaka M, Sakai R, Koike R, Harigai M. Pneumocystis Jirovecii pneumonia in Japanese patients with rheumatoid arthritis treated with tumor necrosis factor inhibitors: a pooled analysis of 3 agents. J Rheumatol. 2015;42:1726-8. 